PROCEEDINGS OF THE UNITED STATES NATIONAL MUSEUM

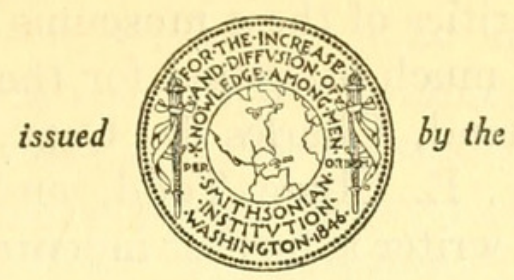

SMITHSONIAN INSTITUTION

U. S. NATIONAL MUSEUM

\begin{tabular}{lll}
\hline \hline Vol. 84 & Washington : 1937 & No. 3018 \\
\hline
\end{tabular}

\title{
A REVISION OF THE CLAPPER RAILS (RALLUS LONGIROSTRIS BODDAERT)
}

\author{
By Harry C. Oberholser
}

Bureau of Biological Survey, United States Department of Agriculture

\section{INTRODUCTION}

The marsh birds called clapper rails form an interesting group. Relatively little from a taxonomic standpoint has been written concerning them, and most of the literature consists of scattered notes and descriptions of new forms. There has been, so far as the writer is aware, no recent publication that could be considered a thoroughgoing review of their characters and relationships, except perhaps that in James L. Peters's recent check-list. ${ }^{1}$ This, however, is intended to be but a check-list, though including the distribution of the various forms. Apparently the best previous treatment of these rails is that by Robert Ridgway in $1880 .^{2}$ About 25 years ago the writer prepared a revision of these rails, which for one reason or another has until now remained unpublished. As several rather unexpected results developed from this study, it seems worth while to put them into print.

For the purpose of this investigation about 500 specimens have been examined, including 21 types, which latter represent nearly all the races. The sources of this material were chiefly the collections of the United States National Museum at Washington, including that of the Biological Survey; the American Museum of Natural History, New York City; the Academy of Natural Sciences of Philadelphia, Pa.;

1 Check-list of birds of the world, vol. 2, pp. 157-160, 1934. Cambridge, Mass.

2 On Raltus longirostris Boddaert, and its geographical races. Bull. Nuttall Orn. Club, vol. 5, no. 3, pp. 138-140, July 1880 . 
the Museum of Comparative Zoology, Cambridge, Mass.; the Carnegie Museum, Pittsburgh, Pa.; the Field Museum of Natural History, Chicago, Ill.; and the private collections of Dr. Jonathan Dwight, Dr. Louis B. Bishop, Dr. Witmer Stone, J. E. Thayer, and J. H. Fleming. To the authorities of these museums and to the individuals mentioned the writer is much obligated for the use of material. To Dr. Charles W. Richmond, Charles B. Cory, Outram Bangs, Dr. Alexander Wetmore, W. E. Clyde Todd, and particularly to Dr. Herbert Friedmann, the writer is further indebted for other courtesies.

In North, Middle, and South America there are approximately 27 forms of large rails belonging to the genus Rallus Linnaeus. These may, in general, be considered to belong to two groups, the king rails (Rallus elegans) and the clapper rails (Rallus longirostris). They have, however, variously been treated as representing from two to six distinct species, some of these with several subspecies.

The first problem of this investigation was presented in the necessity for determining the number of species involved. Examination shows that Rallus longirostris and the other South American forms intergrade completely with Rallus crepitans of the Eastern United States, through the forms inhabiting the West Indies and the Eastern United States, when individual variation of the island forms is taken into consideration. Therefore, the latter must be treated as a subspecies of Rallus longirostris, along with all the forms inhabiting the West Indies. The same is obviously true of the additional races in South America. Furthermore, when all the races represented by a sufficient series are compared with one another it becomes increasingly evident that none of the forms of the Pacific coast can be trenchantly separated, including Rallus obsoletus, Rallus levipes, Rallus beldingi of Lower California, and the other recently described subspecies from northwestern Mexico and southeastern California. Even the isolated Rallus tenuirostris of the Valley of Mexico presents no characters that are not bridged over by individual variation when all the forms are considered. There thus seems to be no alternative to regarding all these as races of a single species. It might be mentioned also that none of these overlap in their breeding distribution.

This accomplished, it remains yet to determine the status of the king rail, Rallus elegans, of the Eastern United States, and its single subspecies, Rallus elegans ramsdeni, of Cuba. This is an unusually difficult matter to decide, and one concerning which there may well be differences of opinion. The chief external characters separating the king rails from the clapper rails consist in the much more reddish bend of the wing, and in the rich rufescent-olive tinge of the upper parts of the former birds, this involving both the centers and margins of the feathers. There is little or no trenchant difference in behavior, voice, nest building, or other habits between these two species. 
Neither one of the external characters of plumage above mentioned, nor any difference in size or proportions, is entirely trenchant when all the races of Rallus longirostris are included. However, even though individually the two species may apparently intergrade in their characters, they sometimes breed in the same areas, as for instance in Texas, Louisiana, Cuba, and North Carolina, where their ranges, at the edges at least, overlap; and it is interesting to note that in these particular places the characters of the two birds are such as to render them easily distinguishable. For the most part Rallus elegans is a fresh-water bird, and Rallus longirostris an inhabitant of the salt marshes, but Rallus elegans sometimes breeds in salt or brackish areas where also there are clapper rails; and some of the subspecies of clapper rails, such as Rallus longirostris yumanensis and Rallus longirostris tenuirostris are strictly fresh-water birds. Furthermore, there is in Cuba a subspecies of Rallus elegans, known as Rallus elegans ramsdeni, although it is separated geographically from the typical Rallus elegans elegans by two or three forms that are certainly subspecies of Rallus longirostris, these being Rallus longirostris insularum, Rallus longirostris waynei, and Rallus longirostris scottii. The two groups can be separated more or less satisfactorily, however, by the use of a combination of characters, in that Rallus elegans presents the combination of a very reddish bend of the wing with a decidedly ochraceous or rufescent tinge on the upper parts, which combination is not found in any form of clapper rail even though each one of these characters may not be separately trenchant. Careful study and comparison are necessary sometimes fully to appreciate these differences, but they are present and are characteristic. In view of the facts above presented it is apparent that we have here what might be regarded as a biological species, and one to which the criterion of intergradation as a test of subspecific relationship is inapplicable. There is a similar case in Europe in the gulls called Larus fuscus and Larus argentatus; and others, in America, as for instance in some species of flycatchers of the genus Empidonax. Under these circumstances it seems best, at least for the present, to consider these birds as representing two species, Rallus elegans consisting of two subspecies, and Rallus longirostris, made up altogether of 25 races. It is with only the latter that we have to do in the present connection.

In a group as variable racially and individually as the clapper rails, examination and study of the whole group reveal the significance of differences in characters, which sporadic investigations wholly fail to do, and this light enables one to predicate distinctions and separations of subspecies much more safely than would otherwise be the case. The group shows a great tendency to break up into local races, many of which have very limited distribution, which accounts in considerable measure for the recognition of so many forms. The most 
valuable characters for subspecific distinction are size and proportions of wing, bill, and other parts, the color of the upper parts, and the color and color pattern of the lower surface. In view of the great individual variation in practically all the forms, comparative descriptions of plumages are of much more value in delineating and identifying the different forms than are detailed descriptions of individual specimens, although the latter are valuable for certain purposes. In making such comparisons, however, the great individual differences of size and color, in nearly all the characters, cause the differences separating the races to be in many cases based on averages; and it is furthermore of much importance in making comparisons between two different races to use birds in the same state of plumage and representing the same color phases.

The range of Rallus longirostris as a species extends north to the Northeastern United States and to northwestern California, south to Lower California, central Mexico, Yucatan, and through the West Indies to Peru and southeastern Brazil. None of the 25 subspecies that are here recognized has what might be called a very extended distribution. With the exception of Rallus longirostris crepitans and Rallus longirostris waynei all the forms are practically resident on their breeding grounds and wander therefrom but little or not at all. The habitat of most of the races is the salt marsh bordering the coast and its inlets, although two of the races, as already indicated, Rallus longirostris yumanensis and Rallus longirostris tenuirostris, inhabit, so far as known, only fresh-water marshes. Some of the others, however, are occasionally found far back from the coast, to show that they do at times live in fresh-water areas, just as Rallus elegans sometimes extends its breeding range over into the salt or brackish marshes. Except in a very general way these birds are not important as indicators of life-zone boundaries, although they have a very interesting connection with ecological associations.

It might be of interest to mention a few of the cases so frequent in plastic species-cases in which a subspecies differs much more in appearance from its nearest geographical neighbors than it does from some far distant relative. For instance, Rallus longirostris cubanus resembles much more Rallus longirostris saturatus than it does either Rallus longirostris scottii or Rallus longirostris insularum, although the two latter separate it geographically from the former. Also, Rallus longirostris waynei is much closer in appearance to Rallus longirostris saturatus than to Rallus longirostris crepitans, or even to Rallus longirostris scottii. Likewise Rallus longirostris saturatus is much more like Rallus longirostris limnetis of Puerto Rico than it is to either Rallus longirostris scottii or Rallus longirostris insularum. Also, Rallus longirostris insularum is nearer to Rallus longirostris saturatus than to Rallus longirostris scottii, and more like Rallus longirostris 
limnetis of Puerto Rico than the intervening Rallus longirostris cubanus. In addition, Rallus longirostris leucophaeus of the Isle of Pines is much more like Rallus longirostris corrius of the Bahama Islands and even nearer Rallus longirostris waynei of South Carolina than it is to either the intervening Rallus longirostris cubanus or the neighboring Rallus longirostris caribaeus. Then, too, Rallus longirostris pallidus of Yucatan is much closer to Rallus longirostris corrius of the Bahama Islands than it is to any of the intervening West Indian races. The bird inhabiting the Valley of Mexico, Rallus longirostris tenuirostris, much more resembles Rallus longirostris beldingi of Lower California than it does the intervening Rallus longirostris nayaritensis. Finally, and the comparisons could be still farther extended, Rallus longirostris crepitans of the coast of the Northeastern United States very much more closely in color approaches Rallus longirostris corrius of the Bahama Islands and Rallus longirostris pallidus of Yucatan than it does any of the geographically intervening races.

Between the adult male and the adult female of this species there is practically no difference in color. The latter, however, is decidedly smaller in average size. The nestling is when hatched approximately 75-80 $\mathrm{mm}$ in length, above jet black with a greenish gloss, below brownish black with a slight greenish gloss anteriorly, but with the abdomen dark blackish clove brown. In some individuals and some races there are slight differences in the color of the lower parts. This plumage is worn until the bird has grown to about twice its original size and the bill to sometimes two and one-half times as long as it was at the beginning. The only color change that takes place during this period is the lightening of the lower surface to clove brown, this then being blackish only anteriorly. The juvenal plumage is similar to that of the adult, but in general differs as follows: The upper surface of the body is plainer and duller with less conspicuous streaking, more like the pattern of the pileum; the sides of the head and neck, particularly the former, are paler, more uniform; the median lower parts are paler, the lower throat, jugulum, and breast with but a trace of ochraceous buff, the throat and jugulum washed also with dull grayish or brownish, often as edgings of the feathers; median portion of breast and abdomen mostly white; sides of the jugulum, breast, and body darker-dull or dark brownish gray, either almost entirely or in the form of edgings of the feathers, producing often a mottled appearance; flanks much paler than in the adult, mouse gray or drab gray with much narrower, less regular, and more inconspicuous whitish bars; and texture of feathers looser than in the adult. The first autumn plumage, which becomes the mature plumage at the end of the first year, is practically identical with that of the adult, but is usually paler below. The last trace of immaturity in plumage is the dusky edgings or mottlings on the sides of the breast, body, and abdomen. 
From the black nestling plumage the young bird molts completely into the juvenal plumage, the neossoptile feathers being borne on the end of the mesoptiles until worn off, this occurring while the bird is still growing, but these fragile down feathers soon drop off and disappear. This nestling plumage may be observed from early in April to late in August, according to local conditions, and the molt from this plumage takes place from about May to September, being completed from July to late in September.

From the juvenal plumage the bird molts into the first autumn plumage by a feather change practically continuous from the downy stage. By the time the bird's bill, feet, wings, and tail are fully grown, which is accomplished sometime between late August and early October, part of the juvenal plumage is in molt; and by the time the wings and tail are fully grown a portion of the juvenal plumage has already disappeared. The first autumn plumage is thence completed sometime between late August and November, by a molt of all the feathers, except those of the wings and tail, which are still those of the juvenal plumage.

Adults molt but once each year, sometime between May and October, occasionally even beginning in mid-April or extending occasionally to late December, or even to January, and there are specimens showing slight evidence of molt on February 2. The contour feathers begin molting first, and the quills during the process of this change. Seasonal differences in the clapper rails consist in the paling of all the colors of the plumage, both above and below, until they become in summer very much bleached. On account of the character of the habitat of this species the feathers also often become very much tattered by friction against the grass. The general color of the back appears sometimes very dark when the black-centered feathers lose their edges by wear.

Individual variation in this species, particularly in color, is on most of the plumage areas very great. The chin and upper throat vary from pure white to distinctly buff; the width of the white bars on the flanks is also variable; as is the color of the flanks, depth of the cinnamon of the breast and of the other lower parts, and likewise the color of the upper surface. So conspicuous are these differences that they obviously represent color phases. These phases are much more evident in some of the subspecies than in others, being practically absent in some like Rallus longirostris corrius and very highly developed in such forms as Rallus longirostris saturatus and Rallus longirostris waynei. In Rallus longirostris saturatus, for instance, there are at least five more or less well-defined color phases that are in no degree due to age, sex, or adventitious condition of plumage, while between these there are all degrees of intermediates. These phases may be briefly described as follows: 
(1) Light gray phase: In this the feathers of the back and scapulars have medium light, somewhat grayish-brown centers, and broad edgings of clear gray.

(2) Dark gray phase: The back and scapulars are much darker, the feathers with very dark brown or blackish centers, the edgings of the feathers much the same as in the light gray phase or somewhat darker.

(3) Light brown phase: In this the feathers of the back and scapulars are centrally rather dark but decidedly rufescent brown, and the edgings are light olive brown.

(4) Dark brown phase: This is similar to the light brown phase, but the centers of the feathers on the back and scapulars are of a very dark brown or black.

(5) Gray-breasted phase: In this very distinct plumage, while the upper parts are like those of the dark brown phase, the whole area of cinnamon on the jugulum and breast is replaced by an almost clear, rather dark gray.

For the names of colors in the following descriptions Ridgway's "Color Standards and Color Nomenclature" (1913) and his "A Nomenclature of Colors for Naturalists" (1886) have been used. All measurements are in millimeters and have been taken in accordance with the recently published manual of measurements, ${ }^{3}$ as follows:

Length of wing: Measured in a straight line from the bend of the closed wing to the end of the longest primary with these feathers in their natural position, that is, not straightened.

Length of tail: Taken with dividers from the point of insertion of the middle pair of rectrices to the tip of the longest, the tail closed.

Exposed culmen: Measured in a straight line from the beginning of the feathers on the culmen to the tip of the maxilla, that is, the chord of the exposed culmen.

Height of bill: The distance in a straight line from the base of the exposed culmen to the nearest point on the ramus of the mandible below.

Length of tarsus: A straight line from the center of the heel joint on the posterior side to the middle of the joint between the metatarsus and the middle toe on the anterior side.

Middle toe: Measured along the upper side from the middle of the joint between the metatarsus and the middle toe to the base of the uncovered claw.

All measurements have so far as possible been taken from typical specimens.

${ }^{3}$ Baldwin, Oberholser, and Worley, Measurements of birds. Sci. Publ. Cleveland Mus. Nat. Hist., vol. 2, Oct. 14, 1931. 


\section{RALLUS LONGIROSTRIS LONGIROSTRIS Boddaert}

\section{Guiana Clapper Rail}

Rallus longirostris Boddaert, Table des planches enluminéez d'histoire naturelle, p. 52, 1783, after Dec. 1 (based on Daubenton, Planches enluminées d'histoire naturelle, pl. "849. Rale a longubec [sic], Buff. XV, p. 251" [="Râle à long Bec de Cayenne" Daubenton, Planches enluminées d'histoire naturelle, pl. 849; Le Râle à Long Bec, Buffon, Histoire naturelle des oiseaux (ed. Deux-Ponts), vol. 15, p. 251; orig. ed., vol. 8, p. 163, 1781 (Guiana)]).

Subspecific characters.-Size relatively small; bill relatively stout; upper parts moderately dark and grayish; lower surface light; the white bars on flanks broad and close together; sides of head light brownish; little grayish on foreneck.

Description.-Adult, U.S.N.M. no. 70685, Demarara, British Guiana. Pileum and hind-neck broccoli brown, in places somewhat rufescent, mixed with grayish feather edgings, which posteriorly impart a streaked appearance; back and scapulars with the feathers centrally deep sepia brown, marginally lighter and dull gray; rump and upper tail-coverts grayish olive brown, the feathers with sepia shaft markings; tail grayish olive brown, the rectrices bister brown centrally; wing-quills bister, the outer edges, together with the superior wing-coverts, lighter, the inner coverts washed with grayish, the outer ones cinnamon; alula light bister, the outer web of outermost feather margined with cinnamon; sides of head and neck dull ochraceous gray, posteriorly darker and indistinctly streaked with pale brownish gray; supraloral stripe paler, a lengthened spot on lower eyelid dull buffy white; chin and upper throat dull pale ochraceous buff; center of lower throat, whole of jugulum, and breast light cinnamon; abdomen dull cream white; sides of body and flanks rather dark grayish brown, rather broadly barred with white; under tail-coverts white, all but some of the longest barred with grayish brown; lining of wing grayish brown, barred narrowly with white; thighs on outer side drab gray, on inner side dull grayish white partly barred with drab gray.

Measurements.-Adult male ${ }^{4}$ : Wing, 133-142 (average, 137.5) mm; tail, 52-59 (55.5); exposed culmen, 54-55 (54.5); height of bill at base, 11-13 (12); tarsus, 46.5-47.5 (47); middle toe without claw, 42.5-43.5 (43). Adult female ${ }^{5}$ : Wing, 126-131 (average, 128) $\mathrm{mm}$; tail, 4757.5 (52.7); exposed culmen, 46-53 (49.3); height of bill at base, 11-13 (12); tarsus, 42.5-47 (44.2); middle toe without claw, 41-44 (41.9)

Type locality.-Cayenne, French Guiana.

Geographic distribution.-Permanent resident from British Guiana to northeastern Brazil.

Remarks. - The bill in this race is apparently stouter than in any form of the species except Rallus longirostris crassirostris. The few

4 Two specimens, from Guiana and Brazil.

${ }^{5}$ Four specimens, from French Guiana, British Guiana, and Brazil. 
specimens examined indicate that there are at least two color phases in this subspecies. One specimen from Guiana is exceedingly pale below and above; in general appearance very close to Rallus longirostris crepitans; and the feathers of the upper parts have very inconspicuous centers. A dark phase is represented by birds from Cayenne and another from Guiana, both of which are more deeply cinnamomeous below, as well as darker above.

Specimens have been examined as follows:

Brazil: Mangunça Island, Maranhão.

British Guiana: Demarara.

French Guiana: Cayenne.

Guiana: (Without specific locality.)

\section{RALLUS LONGIROSTRIS CRASSIROSTRIS Lawrence}

Brazilian Clapper Rail

R[allus]. crassirostris Lawrence, Ann. Lyc. Nat. Hist. New York, vol. 10, p 19 (in text), Feb. to Mar. 1871 ("Bahia" [Brazil]).

Subspecific characters.- Similar to Rallus longirostris longirostris, but bill thicker, upper parts darker, more brownish; sides of head more brownish; anterior under surface much darker, more cinnamomeous; and the white bars on flanks much narrower.

Measurements.-Adult, probable male ${ }^{6}$ : Wing, $138 \mathrm{~mm}$; tail, 52; exposed culmen, 52.5; height of bill at base, 15; tarsus, 40.5 ; middle toe without claw, 46 .

Type locality.-Bahia, Brazil.

Geographic distribution.-Permanent resident in central eastern Brazil, south to southeastern Brazil.

Remarks.-The only specimen certainly of this race examined is the type from Bahia, Brazil, which is no. 45660 of the American Museum of Natural History bird collection. It obviously represents, however, a subspecies distinct from the typical form of the species, which inhabits the Guianas and northeastern Brazil.

\section{RALLUS LONGIROSTRIS CYPERETI Taczanowski}

\section{Peruvian Clapper Rail}

Rallus cypereti Taczanowski (Stolzmann MS.), Proc. Zool. Soc. London, 1877, p. 747, Apr. 1878 ("Santa Luzia", near Tumbez, northwestern Peru).

Subspecific characters.-Similar to Rallus longirostris longirostris but much smaller, with a shorter and slenderer bill; sides of head more brownish (less grayish); anterior lower parts of a brighter, somewhat darker cinnamon; and white bars on sides and flanks narrower. Similar to Rallus longirostris crassirostris but smaller; bill much slenderer; above lighter, more grayish; anterior lower parts of a lighter, rather brighter cinnamon; and the white bars on sides and flanks broader. 
Description.- "Supra olivaceo-griseus fusco maculatus; collo, pectore et striga superciliari flavis; gula abdomineque medio albis; alis caudaque olivaceo-griseis; hypochondriis subalaribusque albo et olivaceo transfasciatis. Rostri brunnei mandibula inferior flavida; pedes olivaceo-carnei; iris rubro-brunnea.

"Forme très-voisine du $R$. longirostris, Vieill. La couleur générale des parties supérieures du corps est d'un gris olivâtre pâle; le dessus de la tête et la nuque sont d'une teinte plus foncée avec des bordures des plumes claires, très-fines et peu distinctes; tout le dos est varié de grosses taches foncées, qui occupent largement le milieu de chaque plume. La gorge est blanche, ainsi que le milieu du ventre; le bas des côtés de la tête, le devant du cou, et la poitrine, ainsi qu'une strie entre la naissance du bec et le bord antérieur de l'œil sont d'une couleur fauve roussâtre claire; un croissant blanc se trouve sur la paupière inférieure dans toute la longueur de l'œil; les côtés du ventre et le bas-ventre sont olive-foncé, striées transversalement de blanc. Les ailes et la queue sont de la couleur du dos; les sus-alaires lavées de roussâtre, les sous-alaires olive-foncé, variées transversalement de raies blanches, fines et peu nombreuses; les plus grandes couvertures inférieures de la queue sont blanches rayées en travers d'olive foncé, les autres blanches en entier. Le bec est brun corné, avec la mandibule inférieure jaunâtre dans sa plus grande moitié basale, ainsi que le bord de la mandibule supérieure; les pattes sont d'une couleur carnée olivâtre; l'iris brun rougeâtre." 7

“Longueur de l'aile pliée

de la queue

du bec, depuis la commissure

du tarse

du doigt du milieu

de l'ongle

du pouce

de l'ongle

\begin{tabular}{rc}
\multicolumn{1}{c}{ đ } & q \\
millim. & millim. \\
137 & 125 \\
60 & 60 \\
52 & 51 \\
44 & 40 \\
40 & 37 \\
9 & 8 \\
11 & 10 \\
5 & 4,7
\end{tabular}

Measurements. ${ }^{8}$-Adult male: Wing, $126 \mathrm{~mm}$; tail, 51; exposed culmen, 52 ; height of bill at base, 12.8 ; tarsus, 49 ; middle toe without claw, 41. Adult female ${ }^{9}$ : Wing, 118; tail, 49; exposed culmen, 50; height of bill at base, 10 ; tarsus, 45 ; middle toe without claw, 37 .

Type locality.-Santa Luzia, near Tumbez, northwestern Peru.

Geographic distribution.-Permanent resident in the coast region of northwestern Peru (Tumbez) to western Ecuador (Vacquia).

Remarks.-This geographically far separated subspecies seems to have, like many other forms of the species, a relatively limited range. In fact, it is known from only two localities. In the color of its upper parts it is practically identical with Rallus longirostris longirostris.

7 Original description from Taczanowski, op. cit., pp. 747-748.

8 One specimen, from Ecuador.

One specimen, from Ecuador. 
RALLUS LONGIROSTRIS PELODRAMUS, new subspecies

\section{Trinidad Clapper Rail}

Subspecific characters.- Similar to Rallus longirostris longirostris, but upper parts, including wings and tail, much darker; edgings of dorsal and scapular feathers somewhat more rufescent; lower surface darker.

Description.-Type, adult male, J. H. Fleming collection no. 20715; Caroni Swamp, Island of Trinidad, March 16, 1902; Bodington. Forehead, crown, and occiput clove brown, more or less conspicuously but rather narrowly streaked with brownish olive and light brownish olive, the feathers of the forehead with stiff shiny blackish shafts; hind-neck, back, and scapulars warm dark clove brown, much streaked by the broad brownish-olive and light brownish-olive edgings of the feathers; rump and upper tail-coverts warm clove brown, the feathers very broadly margined with olive brown; rectrices warm clove brown, passing laterally into olive brown; primaries and secondaries sepia, rather lighter on their outer margins; tertials dark clove brown, broadly edged with light brownish olive; primary coverts rather grayish sepia; lesser wing-coverts light brownish olive; remaining upper wing-coverts between snuff brown and Saccardo's umber, many of the feathers with ill-defined sepia shaft streaks; alula sepia, the exterior web of outermost feather with more or less dull ochraceous buff along its margin; sides of head grayish buffy brown, passinginto grayish olive brown on lores and rictal region; a narrow supraloral streak dull ochraceous buff, and a lengthened spot on lower eyelid dull buffy white; sides of neck dull buffy brown, obscurely streaked with dull olive brown; chin and upper throat white, with but a suggestion of creamy tinge, laterally dull pinkish cinnamon; jugulum and breast dull cinnamon, laterally much overlaid or mixed with light olive grayish or olive brownish; abdomen dull white; sides and flanks fuscous, heavily barred with white, these bars from 1.5 to $3 \mathrm{~mm}$ in width; thighs exteriorly dull pale brownish, interiorly dull buffy whitish; lining of wing fuscous, the axillars rather broadly, the under wing-coverts narrowly, barred with white. "Iris reddish brown; upper mandible and tip of lower, blackish brown; rest of lower mandible pale brownish red; feet brown with darker markings."

Measurements.-Adult male ${ }^{10}$ : Wing, $131.5 \mathrm{~mm}$; tail, 54 ; exposed culmen, 51.8 ; tarsus, 47.5 ; middle toe without claw, 46.5 .

Type locality.-Caroni Swamp, Island of Trinidad.

Geographic distribution.-Permanent resident on the Island of Trinidad.

Remarks.-This new race is much different from Rallus longirostris longirostris, of Guiana, by reason of its very dark colors, as already

10 One specimen, the type. 
detailed, but it agrees with that form in the stoutness of the bill, in which character it thus differs from all the West Indian, Central American, and North American forms of the species. From Rallus longirostris crassirostris it may be distinguished by its rather shorter wing, slenderer bill, wider white bars on sides and flanks, and darker coloration.

The type of this new subspecies is the only specimen that the writer has had opportunity to examine.

RALLUS LONGIROSTRIS MANGLECOLA Danforth

Antigua Clapper Rail

Rallus longirostris manglecola Danforth, Proc. Biol. Soc. Washington, vol. 47, p. 19, Feb. 9, 1934 ("Five Islands, Antigua").

Subspecific characters.--Similar to Rallus longirostris longirostris but larger; bill much longer and slenderer; white bars on sides and flanks narrower; entire upper parts, including wings, tail, and sides of head and of neck, darker; and sides of head more purely grayish.

Description.-Brown phase, immature, sex unknown, U.S.N.M. no. 76386, Guadeloupe Island, West Indies; F. A. Ober. Forehead, crown, and occiput rather grayish sepia brown, slightly and obscurely streaked with lighter brown, the feathers of forehead with stiff, shiny, blackish clove brown shafts; upper hind-neck olive brown, somewhat streaked with light drab; lower portion of hind-neck, with all the back and scapulars, between sepia and bister but mostly darker than either, the feathers edged, often broadly, with Saccardo's umber, light brownish olive, grayish olive, light grayish olive, and smoke gray; rump and upper tail-coverts rather deep sepia, the feathers mostly margined with brownish olive; rectrices between bister and sepia, darker medially, and passing laterally into olive brown or buffy brown; primaries and secondaries dark mummy brown, lighter on the latter and on the external margins of primaries; tertials dark brown like the back, broadly edged with Saccardo's umber and light brownish olive; primary coverts mummy brown; greater wing-coverts between bister and sepia or between bister and snuff brown, becoming snuff brown laterally; lesser and median coverts Saccardo's umber, the former with shaft streaks of sepia; alula mummy brown, the exterior web of outermost feather spotted obscurely with dull ochraceous buff; sides of head mouse gray, the lores more brownish, a narrow supraloral streak dull ochraceous buff, and a lengthened spot on lower eyelid dull buffy white; sides of neck rather light olive brown, obscurely streaked with drab gray and buff; chin and upper throat white, with a very faint creamy tinge, laterally pale ochraceous buff; jugulum anteriorly pale ochraceous buff, deepening into pinkish cinnamon posteriorly and on middle of breast, but everywhere somewhat overlaid with light gray; 
sides of breast and middle of lower breast and of upper abdomen hair brown (this a remnant of the juvenal plumage); abdomen dull white; sides and flanks hair brown, narrowly barred with dull white; thighs exteriorly between hair brown and drab, interiorly very pale dull grayish buffy or ochraceous white; lining of wing mixed hair brown and snuff brown, passing posteriorly into clear hair brown, and everywhere much narrowly barred with white.

Measurements.-Adult male ${ }^{11}$ : Wing, $146.1 \mathrm{~mm}$; tail, 60.5 ; exposed culmen, 73.9 ; tarsus, 54 ; middle toe without claw, 50 . Adult female ${ }^{12}$ : Wing, 135.5; tail, 60.7; exposed culmen, 64.8; tarsus, 45.8. Immature, probable male ${ }^{13}$ : Wing, 148 ; tail, 62 ; exposed culmen, 64.5 ; tarsus, 51.5 ; middle toe without claw, 50 .

Type locality.--Five Islands, Antigua Island, West Indies.

Geographic distribution.-Permanent resident on the West Indian Islands of Antigua and Guadeloupe.

Remarks.-This race is similar to Rallus longirostris pelodramus, of Trinidad, but is much larger, the bill being much longer and slenderer, the upper parts lighter and more rufescent, the centers of the feathers less blackish (more brownish), and the margins of the feathers there less grayish; the lower parts are lighter, and the center of the jugulum has some gray wash, being not purely cinnamomeous. There are two color phrases involving the color of the upper parts, one gray, the other brown.

A single specimen in fully developed juvenal plumage from the Island of Guadeloupe, collected by F. A. Ober, is apparently the only certain record of the occurrence of a clapper rail on this island. This specimen, though fully grown, still possesses some of the dark juvenal plumage on portions of the breast and abdomen, but otherwise, particularly on the upper surface, it has acquired the full adult livery. Although it exhibits some difierences from the average of the other West Indian forms of the species, it seems best, at least for the present, in view of its immaturity, to refer it to Rallus longirostris manglecola, which it most closely resembles. It is, however, in the brown phase, and thus differs materially in color from the type of this form. It may, however, be regarded as the brown phase of this subspecies. For purposes of comparison it has been described above.

The following specimens of Rallus longirostris manglecola have been seen:

Antigua Island, West Indies: Five Islands (August 10, 1933). $\cdot^{14}$ Guadeloupe Island, West Indies: (No further locality.)

11 One specimen, the type.

12 One specimen measured by Danforth, loc. cit.

13 One specimen, from Guadeloupe Island.

14 Type. 


\section{RALLUS LONGIROSTRIS LIMNETIS, new subspecies}

Puerto Rico Clapper Rail

Subspecific characters.-Similar to Rallus longirostris manglecola, but bill and tarsus shorter; upper parts somewhat more grayish (less rufescent), particularly on the lower back; edgings of back and scapulars also paler, giving a rather lighter tone to these parts; and cinnamon of jugulum and breast paler.

Description.-Dark phase. Type, adult male, U.S.N.M. no. 232261, Biological Survey collection; Punta Picua, Mameyes, Puerto Rico, February 12, 1912; Alexander Wetmore, original number, 1225. Forehead and crown bister, most of the feathers with stiff, shiny, blackish shafts; occiput sepia; hind-neck olivaceous hair brown, somewhat mixed, particularly on posterior portion, with narrow brownishgray edgings, which give a somewhat streaked appearance; feathers of back and scapulars centrally varying from clove brown on the scapulars to bister on the rest, marginally smoke gray, brownish gray, or olive gray; rump and upper tail-coverts olivaceous bister, with broad olive or dull olive-gray feather margins; rectrices olivaceous bister brown, darker medially, and more or less broadly edged laterally with olive; primaries and secondaries bister, rather lighter on their margins; tertials like the scapulars, but their centers more blackish; greater wing-coverts rather light bister; their inner webs somewhat more rufescent; median coverts centrally somewhat rufescent clove brown, marginally varying from hair brown to brownish gray; lesser coverts between bister and Saccardo's umber; alula rather light bister, the outer web of outermost feather mottled with cinnamon; sides of head neutral gray, the lores, together with a rather broad continuous stripe below the eyes through the auriculars, grayish hair brown, a lengthened spot on lower eyelid dull grayish white, a narrow supraloral streak pale dull buff; sides of neck and of lower throat between broccoli brown and hair brown, posteriorly inclining to broccoli brown and indistinctly streaked with paler brown; chin and upper throat white, laterally rather deep cream buff; middle of lower throat dull buff; jugulum isabella color; breast between pinkish cinnamon and vinaceous buff, somewhat whitish medially on the posterior portion; abdomen dull white, slightly washed with cream color; sides of body and flanks dark hair brown, rather broadly barred with white; lower tail-coverts white, the middle feathers and also the shorter feathers broadly barred with fuscous; lining of wing anteriorly bister brown, passing posteriorly into blackish fuscous, and narrowly barred with white throughout; thighs interiorly grayish cream color, exteriorly grayish benzo brown. "Iris reddish hazel; culmen and end of lower mandible brown, the base of bill reddish; legs liver color; fore part of tibiae redder" (Newton). 
Downy young.- "Bill with the under mandible and distal half of the upper as well as an elongated patch over each nostril bright scarlet, the rest livid black" (Newton).

Measurements.-Adult male ${ }^{15}$ : Wing, 138.5-150 (average, 145.5), $\mathrm{mm}$; tail, 56.5-63.5 (61.2); exposed culmen, 62-68 (63.9); tarsus, 50-56.5 (54.2); middle toe without claw, 47-49.5 (47.4). Adult female ${ }^{16}$ : Wing, 136.5-139.5 (137.6); tail, 56-60 (57.7); exposed culmen, 55-60 (58.2); tarsus, 43.5-50 (47.4); middle toe without claw, 41.5-43.5 (42.5).

Type locality.-Punta Picua, Mameyes, Puerto Rico.

Geographic distribution.-Permanent resident in the West Indian Islands of Puerto Rico, Culebra, Vieques, Tortola, St. Croix, and St. Thomas.

Remarks.-This is the West Indian race that apparently most closely approaches Rallus longirostris longirostris, but nevertheless its bill is decidedly longer and slenderer than is that of the typical race; the upper parts, including the sides of the head and of the neck, and the upper surface of the wings are darker; and the sides and flanks have narrower white bars.

In Rallus longirostris limnetis the jugulum nearly always has more or less gray, although occasionally it is practically absent, this part then being plain cinnamomeous.

The birds from St. Thomas appear to be somewhat more brownish (less grayish) on flanks and upper parts, thus verging a little toward Rallus longirostris caribaeus, but they are so close to Rallus longirostris limnetis that they seem best referred to this race.

So far as our specimens show there are two well-defined color phases in this subspecies - a light phase and a dark phase. There is apparently no gray-breasted or brown phase, notwithstanding the fact that there is great individual variation on the upper parts, though not so much on the lower surface. For purposes of comparison the following description of the light phase may be useful:

Adult male, U.S.N.M. no. 80997; St. Thomas Island, West Indies; F. A. Ober, original number, 34. Forehead and crown brown, between snuff brown and bister, most of the feathers with stiff, shiny, bister shafts; occiput and upper cervix olive brown; rest of hindneck buffy brown, mixed, particularly on posterior portion, with hairbrown edgings, which impart a somewhat streaked effect; feathers of the back and scapulars centrally varying from buffy brown to olive brown and sepia, marginally smoke gray, light grayish olive, or olive gray; rump and upper tail-coverts olive brown, the edgings of the feathers rather lighter and inclining to dull grayish olive; rectrices olive brown, deepening to sepia medially, and rather lighter, more

15 Eleven specimens, from Puerto Rico, Culebra Island, and St. Thomas.

16 Five specimens, from Puerto Rico and St. Thomas. 
grayish, or olivaceous marginally; primaries and secondaries mummy brown, rather lighter on the external webs, which are narrowly margined with olivaceous; tertials dark brown, between clove brown and sepia, broadly edged with light grayish olive and dull grayish olive; primary coverts mummy brown; greater and median wing-coverts between mummy brown and Prout's brown, the inner ones more or less broadly margined with dull grayish olive, some of the greater coverts somewhat tinged with cinnamon brown, also a little spotted or irregularly barred with ochraceous buff or whitish; lesser wingcoverts Saccardo's umber; alula between mummy brown and Prout's brown, sparingly and faintly barred with dull ochraceous buff, the outer web of the outermost feather almost wholly of this color; sides of head rather light mouse gray, the lores, together with a rather narrow subocular stripe, buffy brown; a lengthened spot on lower eyelid and a supraloral streak light buff; sides of neck and middle of upper jugulum grayish olive, more or less mixed with pale ochraceous buff and light ochraceous buff; chin and upper throat dull creamy white, laterally pinkish buff; middle of lower throat pinkish buff, somewhat dulled by an admixture of pale gray; breast and lower part of jugulum between cinnamon buff and pinkish cinnamon, slightly dulled by a faint wash of whitish or pale grayish; abdomen dull white; sides and flanks between buffy brown and hair brown, rather narrowly barred with dull white; lower tail-coverts white, most of the feathers heavily barred with grayish clove brown; thighs exteriorly drab, faintly barred with pale dull buff, anteriorly dull grayish cream color; lining of wing anteriorly mostly cinnamon brown, posteriorly soon passing into dark hair brown, and everywhere narrowly barred with white.

Specimens from the following localities have been examined:

Culebra Island, Puerto Rico, West Indies: Playa Sardine (April 12, 1912).

Puerto Rico: La Playita, Salinas (May 2, 1912, April 29, 1912, April 30, 1912); Punta Picua, Mameyes (February 12, 1912); San Juan (January 4, 1899); La Playa, Manati (July 8, 1912). ${ }^{17}$

St. Thomas Island, Virgin Islands: (No definite locality) (1860).

RALLUS LONGIROSTRIS VAFER Wetmore

Hispaniolan Clapper Rail

Rallus longirostris vafer Wetmore, Proc. Biol. Soc. Washington, vol. 41, p. 121, June 29, 1928 ("Etroite, Gonave Island, Haiti").

Subspecific characters.-Similar to Rallus longirostris limnetis, but wing and tarsus longer, tail and middle toe somewhat longer; upper parts in dark phase darker, averaging somewhat more olivaceous (less 
grayish); upper parts in light phase averaging lighter; both dark and light phases averaging darker on the lower parts.

Measurements.-Adult male ${ }^{18}$ : Wing, $151-159.5$ (average, 155$) \mathrm{mm}$; tail, 61.5-66.4 (63.3); exposed culmen, 63.8-68.5 (65.5); tarsus, 57-61 (59); middle toe without claw, 50-54 (51.9). Adult female ${ }^{19}$ : Wing, 134.5-144.5 (138.4); tail, 54.4-60 (56.9); exposed culmen, 53.6-63 (58.7); tarsus, 46.4-59.5 (52.8); middle toe without claw, 40.5-45 (43.6).

Type locality.-Etroite, Gonave Island, Haiti.

Geographic distribution.-Permanent resident in Haiti and Dominican Republic, with their coastal islands.

Remarks.- In this race there is nearly always more or less gray on the central portion of the jugulum. There are four well-defined color phases-light brown, dark brown, light gray, and gray-breasted dark brown.

The following specimens have been examined:

Haiti: Caracol (April 27, 1927); Etroite, Gonave Island (March 18, 1920, ${ }^{20}$ and March 19 and 20, 1920); Pekim, Gonave Island (July 7 and 8, 1920); Petite Gonave (March 19, 1930); Fort Liberté (February 18, 1929); Petit Trou de Nippes (April 9, 1930); Grande Cayemite (April 11, 1930).

Dominican Republic: Monte Cristi (February 18, 1916).

\section{RALLUS LONGIROSTRIS CORRIUS Maynard}

\section{Bahama Clapper Rail}

Rallus Corrius Maynard, Amer. Exchange and Mart, vol. 3, no. 5, p. 33, col. 2, Jan. 15, 1887 ("an Island off the south shore of Andros [Island, Bahama Islands]").

Rallus Coryi Maynard, Amer. Exchange and Mart, vol. 3, no. 6, p. 69, col. 3, Feb. 5, 1887 ("an island off the south shore of Andros [Island, Bahama Islands]").

Subspecific characters.- Similar to Rallus longirostris limnetis, but bill, tarsus, and middle toe shorter; upper and lower parts very much paler.

Description of soft parts.- "Iris red brown; bill orange brown, except culmen and tip, which are blackish; legs and feet brownish orange" (W. W. Worthington).

Measurements.-Adult male ${ }^{21}$ : Wing, 137-150 (average, 146) mm; tail, 53.5-67 (61.3); exposed culmen, 53-65 (59.5); tarsus, 45-53.5 (49.4); middle toe without claw, 44.5-49.8 (47.8). Adult female ${ }^{22}$ :

\footnotetext{
${ }^{18}$ Four specimens, from Haiti; measurements, except for the middle toe, taken by Wetmore, loc. cit.

10 Seven specimens, from Haiti and Dominican Republic; measurements, except for middle toe, taken by Wetmore, loc. cit.

${ }_{20}$ Type.

${ }^{21}$ Seven specimens, from the Bahama Islands.

22 Ten specimens, from the Bahama Islands.
} 
Wing, 128.5-141 (134.7); tail, 54-62 (57.5); exposed culmen, 52-60.5 (55.3); tarsus, 42-50 (46.9); middle toe without claw, 38.5-45 (43.2).

Type locality.-An island off the southern shore of Andros Island, Bahama Islands.

Geographic distribution.-Permanent resident in the central and northern Bahama Islands, north to Abaco Island and Berry Islands; west to Andros Island and the keys nearby; south to Ragged Island; and east to Watling Island, New Providence Island, and Eleuthera Island.

Remarks.-The Bahama clapper rail differs from Rallus longirostris longirostris in somewhat longer wing and bill, slenderer bill, and much paler coloration throughout. Birds from the various islands of the Bahama group, so far as our material goes, apparently exhibit no geographic differences. There are, furthermore, no well-marked color phases in this subspecies.

This rail was originally described by C. J. Maynard in a littleknown publication, along with other new birds from the Bahama Islands. His original description called the bird Rallus Corrius ${ }^{23}$ but there is no evidence in this original place of description that the spelling of the specific name was a typographical error. At a later date, however, in the same journal Mr. Maynard republished this description and there called the bird Rallus Coryi ${ }^{24}$ evidently intending this name to replace Rallus Corrius, although he did not so state. Current rules of zoological nomenclature permit no change in the original spelling of technical specific names, aside from the change in termination necessary to make specific and subspecific names agree in gender with their generic names, and also cases in which a typographical error is obvious in the original publication. The word "Corrius" could easily have been formed as an adjective from Mr. Cory's name; so that under the circumstances it seems more logical to use this form rather than the emendation later proposed.

The writer has examined specimens from the following localities:

Bahama Islands: Key south of Andros Island (April 29, 1884) ${ }^{25}$; South Andros Island (May 22, 1904, June 14, 1904); Southern Ragged Island (April 6, 1907); Berry Islands (April 7 and 8, 1891); Marsh Harbor, Abaco Island (July 6, 1904); Staniard Creek, Andros Island (April 15, 1909); New Providence Island (June 24, 1903); Watling Island (March 17, 18, 22, and 27, 1909; and August 17, 1923); Lake Isabella, Watling Island (March 23, 1909).

${ }^{23}$ Amer. Exchange and Mart, vol. 3, no. 3, p. 33, col. 2, Jan. 15, 1887.

24 Amer. Exchange and Mart, vol. 3, no. 6, p. 69, col. 3, Feb. 5, 1887.

2s Type. 


\section{RALLUS LONGIROSTRIS CUBANUS Chapman}

\section{Cuban Clapper Rail}

Rallus longirostris cubanus Chapman, Bull. Amer. Mus. Nat. Hist., vol. 4, p. 288, Dec. 29, 1892 ("Casilda, coast of southern Cuba").

Subspecific characters.-Similar to Rallus longirostris limnetis, but wing longer; bill averaging somewhat shorter; tarsus and middle toe shorter; upper parts much darker and somewhat more brownish (less grayish); lower parts darker, particularly the breast, sides, and flanks, the last two usually with narrower white bars.

Measurements.-Adult maie ${ }^{26}$ : Wing, 142.5-159 (average, 149) mm; tail, 57-67 (61.8); exposed culmen, 58-66 (62.7); tarsus, 52.5-55.5 (54.9); middle toe without claw, 45-51.5 (48.2). Adult female ${ }^{27}$ : Wing; 128-139.5 (132.6); tail, 49-65 (58.5); exposed culmen, 57-61 (59); tarsus, 48-54 (52); middle toe without claw, 43.5-45.5 (44.8).

Type locality.-Casilda, near Trinidad, on the southern coast of Cuba.

Geographic distribution.-Permanent resident of the island of Cuba.

Remarks. - The Cuban clapper rail differs from Rallus longirostris manglecola in shorter bill, in having the ground color of the upper surface somewhat darker, less rufescent (more grayish), the upper wing-coverts less uniform and darker, the cinnamon of breast paler and duller.

The present race and Pallus longirostris corrius represent two extremes in coloration, and the former is so very much darker, more brownish above, and so much darker below, particularly on the sides and flanks, and has such narrow white bars on the flanks that it is separable at a glance. There are three well-marked color phases in this subspecies, a light gray, a dark gray, and, though the middle of the jugulum is more or less grayish in practically all the specimens, also a gray-breasted phase, in which the cinnamon on the breast disappears and is replaced entirely by grayish, while all the rest of the under parts is more or less clearly grayish. Very pale specimens of the lightgray phase sometimes resemble specimens of other races.

The following specimens have been examined:

Cuba: Mariel (May 10, 1900); Boqueron (August 19, 1930); Manzanillo, Oriente (September 2 and 3, 1930); Casilda, near Trinidad (April 14, 1892) ${ }^{28}$; Preston (March 6 and 15, 1915, February 23 and 27, 1915); wharf on Los Canos Estate, Manati, Guantanamo (February 29, 1912); Guantanamo (July 3, 1908, August 10, 1909, April 4, 1910, October 3, 1910).

${ }^{26}$ Eight specimens, from Cuba.

${ }^{27}$ Four specimens, from Cuba.

${ }^{38}$ Type. 


\section{RALLUS LONGIROSTRIS LEUCOPHAEUS Todd}

Isle of Pines Clapper Rail

Rallus longirostris leucophaeus Tod, Proc. Biol. Soc. Washington, vol. 26, p. 174, Aug. 8, 1913 (“Majagua River, Isle of Pines").

Subspecific characters.- Similar to Rallus longirostris cubanus, but wing averaging somewhat shorter; upper parts more grayish (less brownish), and averaging somewhat lighter; jugulum, sides, flanks, and crissum more grayish (less rufescent), and the middle of the abdomen much paler cinnamon buff, barely tinged with this color, or white, and the white bars on flanks broader.

Description.-Type, adult male, Carnegie Museum no. 39717, Majagua River, Isle of Pines, November 7, 1912; G. A. Link, original number, 262.

Forehead, crown, and occiput fuscous, many of the feathers of the forehead and crown with stiff, shiny, black shafts; hind-neck between hair brown and deep mouse gray, becoming on posterior portion like the pileum, and a little, but narrowly and inconspicuoulsy, streaked with light dull gray edgings of the feathers; feathers of the back medially clove brown, of the scapulars fuscous black, all margined, but more broadly on posterior portions, with light mouse gray; rump and upper tail-coverts clove brown, with very broad mouse-gray feather margins; rectrices medially fuscous black, the outer margins widely mouse gray verging to deep mouse gray, the inner margins clove brown; primaries and secondaries brown, between clove brown and bister, the inner margins paler, the outer edges bister; tertials like the scapulars; greater wing-coverts olive brown, with narrow more or less irregular whitish and buffy bars; median and lesser coverts between Saccardo's umber and sepia, basally rather more tawny, the inner ones somewhat grayish; alula between benzo brown and fuscous, the two long feathers irregularly barred with cream color and cream buff; lores and rictal region hair brown; supraloral streak dull cream buff; and elongated spot on lower eyelid dull white; remainder of the sides of head, together with the sides of neck, gray, between pale mouse gray and smoke gray; chin and throat white; middle of lower throat dull white, very slightly washed with buff; sides of jugulum gray like the sides of the neck but a little darker and slightly washed with buff; middle of jugulum dull pale ochraceous buff; breast and middle of abdomen grayish cream white washed laterally with pale ochraceous buff, and shading into the buff of jugulum on the anterior portion of the breast; flanks and sides of body somewhat light chaetura drab, rather narrowly barred with white; lower tail-coverts white, all but the longer lateral feathers broadly barred with the chaetura drab of the flanks, these dark bars much wider than the white interspaces; lining of wing anteriorly fuscous, posteriorly shading into the 
brownish chaetura drab of the flanks, and narrowly barred throughout with dull white; thighs posteriorly cream color, anteriorly mouse gray.

Measurements.-Adult male ${ }^{29}$ : Wing, $135-155$ (average, 146) $\mathrm{mm}$; tail, 57.5-67.5 (61.8); exposed culmen, 60.5-66 (63.3); tarsus, 50-59 (55.3); middle toe without claw, 44-49.5 (46.4). Adult female ${ }^{30}$ : Wing, 127.5-149 (134.3); tail, 53-62.5 (58.6); exposed culmen, 51.559.5 (56.3); tarsus, 45-51.5 (49.3); middle toe without claw, 39-43.5 (41.2).

Type locality.-Majagua River, Isle of Pines, West Indies.

Geographic distribution.-Permanent resident on the Isle of Pines.

Remarks.-This clapper rail differs from Rallus longirostris limnetis of Puerto Rico in darker, more grayish upper surface; darker lower surface, the sides and flanks more slaty or grayish (less rufescent), the cinnamon of the anterior lower parts decidedly paler; middle of abdomen with much less wash of cinnamon buff, or entirely white; and the white bars on sides and flanks somewhat narrower. It is similar to Rallus longirostris corrius of the Bahama Islands but has a longer tarsus and is very much darker above, with the centers of the feathers more blackish, the anterior lower parts, together with the sides, flanks, and crissum, much darker, the flanks with narrower bars, the throat and breast of much darker cinnamon buff.

Individual variation in this race is great, as in most of the races of clapper rails, and consists chiefly in the darker shade of the head and hind-neck; darker, more blackish upper parts in some specimens; the rufescence of the wing in certain individuals; the extent of the white area on the throat, and of the median white area on the foreneck and abdomen. In some specimens the median white area on the foreneck is barely interrupted by the gray of the jugulum, though in most specimens this area is thus definitely interrupted. The cinnamon buff on the chest ranges from almost none to a rather deep suffusion; the width of the white bars on the flanks varies also; the lower tail-coverts are sometimes mostly white barred with black, and sometimes mostly black barred with white; and the depth of the gray on the jugulum is much darker in some specimens than in the type.

In normal phase this subspecies is moderately cinnamomeous below and gray above, but there are two phases above, a gray and a brown, and below a light phase, a dark phase, and a gray-breasted phase. In the last-mentioned the lower parts except for the chin and middle throat, flanks, and sides, and crissum are brownish gray, deepest on the jugulum, breast, and sides of the breast, somewhat tinged with cinnamon buff on the middle of the breast, and much paler but not buffy on the middle of the abdomen. The upper parts in the brown phase are very much like those in the brown phase of Rallus longirostris

${ }^{29}$ Twelve specimens, from the Isle of Pines.

${ }^{30}$ Twelve specimens, from the Isle of Pines. 
saturatus, but compared with the normal (gray) phase of the present race they are more blackish, owing to the darker, more extensive centers of the feathers, with the bend of the wing more rufescent and the upper parts more rufous or ochraceous, the lower parts more deeply and brightly cinnamomeous; in fact, superficially the whole bird in brown phase looks very much like Rallus elegans. What might be considered the normal phase of this subspecies is moderately cinnamomeous below and gray above.

Specimens from the following localities bave been seen:

Isle of Pines, West Indies: Los Indios (September 27 and 30, 1912, October 3, 9, and 29, 1912); Majagua River (November 7, 1912, ${ }^{31}$ October 26, 1912); Nueva Gerona (March 12, 13,14, 16, and 19, 1917).

\section{RALLUS LONGIROSTRIS CARIBAEUS Ridgway}

\section{Caribbean Clapper Rail}

[Rallus longirostris] c. var. caribaeus RIDGWAY, Bull. Nuttall Orn. Club., vol. 5, no. 3 , p. 140 , July 1880 ("West Indies").

Subspecific characters.-Similar to Rallus longirostris cubanus but lighter and more uniform both above and below, the centers of the feathers on the back and other posterior upper parts much less blackish, less sharply contrasted with edgings; white bars on flanks broader.

Measurements.-Adult male ${ }^{32}$ : Wing, 148.5-150 (average, 149.2) $\mathrm{mm}$; tail, 60-66.5 (63.2); exposed culmen, 58.5-62 (60.2); tarsus, 53-55 (54); middle toe without claw, 48-50 (49). Adult female ${ }^{33}$ : Wing, 142.5; tail, 61.5; exposed culmen, 55; tarsus, 49; middle toe without claw, 44 .

Type locality.-Spanish Town, Jamaica, West Indies.

Geographic distribution.-Permanent resident in Jamaica.

Remarks.-The present race differs from Rallus longirostris manglecola in shorter bill; in having the ground color of the upper parts, including the wings, of a lighter, more rufescent brown, the edgings also more brownish (less grayish); cheeks and sides of neck more rufescent (less grayish); and the anterior lower parts lighter, duller, less pinkish (more ochraceous) cinnamon.

It differs from Rallus longirostris longirostris in longer wing, darker upper parts, and somewhat narrower white bars on the flanks; from Rallus longirostris corrius in somewhat larger size, much darker upper and lower surfaces, and somewhat narrower white bars on the flanks; from Rallus longirostris limnetis in shorter bill, more rufescent (less grayish) upper surface, this including both the centers and margins of the feathers; duller, more ochraceous jugulum and breast, and more rufescent sides and flanks. From Rallus longirostris leucophaeus of the Isle of Pines it may be readily separated by its shorter bill, lighter, 
more brownish (less grayish) upper surface, the feather centers there much less blackish and much lighter; less grayish (more brownish) lower surface, the anterior parts being duller and more uniform ochraceous buff.

In this race the jugulum is slightly but more or less evenly washed with grayish, making the color of this part rather dull. All the specimens that the writer has seen are in what might be taken for the brown phase, as there are no grayish birds among them.

Specimens from the subjoined localities have been examined:

JAMAICA: Near Spanish Town ${ }^{34}$; Great Salt Pond (January -, 1865).

\section{RALLUG LONGIROSTRIS PALLIDUS Nelson}

Yucatan Clapper Rail

Rallus pallidus Nelson, Proc. Biol. Soc. Washington, vol. 18, p. 141, June 9, 1905

(“Rio Lagartos, Yucatan, Mexico").

Subspecific characters.- Similar to Rallus longirostris caribaeus, but upper parts decidedly lighter; flanks darker; and the cinnamon of lower surface more pinkish (less ochraceous).

Measurements.-Adult female ${ }^{35}$ : Wing, $143 \mathrm{~mm}$; tail, 59.5; exposed culmen, 53 ; tarsus, 48 ; middle toe without claw, 48.

Type locality.-Rio Lagartos, northwestern Yucatan, Mexico.

Geographic distribution.-Permanent resident in northern Yucatan and eastern Quintana Roo, Mexico.

Remarks.-This clapper rail differs from Rallus longirostris crepitans in having the bill shorter, upper parts including wings, particularly the mesial stripes, and tail more rufescent (less grayish). It may be separated from Rallus longirostris corrius by the longer wing and middle toe, and darker breast, flanks, and upper parts. The only specimen known up to the present time is the type, but also the clapper rail recorded from eastern Quintana Roo by Griscom belongs probably to this race.

RALLUS LONGIROSTRIS BELIZENSIS, new subspecies

\section{Honduras Clapper Rail}

Subspecific characters.-Similar to Rallus longirostris pallidus, but upper surface, including the crown, very much darker, the dark centers of the feathers blackish instead of olive brown, but the edgings of the feathers lighter, more purely gray.

Description.-Type, adult female, no. 19747, collection of E. A. and O. Bangs; Ycacos Lagoon, British Honduras, May 14, 1907; Morton E. Peck.

34 Type.

35 One specimen, the type. 
Pileum and hind-neck sepia brown, the latter somewhat streaked with narrow dull buff feather edgings; scapulars, interscapulars, and tertials with centers of clove brown and margins of clear medium gray, giving a conspicuously streaked appearance; rump and upper tail-coverts dark brown (between clove brown and sepia), broadly margined with dull olive gray; tail-feathers rather light bister brown, with central stripes of clove brown, broadest on the two middle pairs; primaries and secondaries sepia, the outer superior margins lighter; alula light bister brown, barred on exterior webs of feathers with cinnamon; upper wing-coverts exteriorly light bister brown, the greater and median series interiorly becoming grayish with clove brown shaft streaks, the greater coverts with a few narrow bars and speckles of whitish; sides of head olive gray, with a white supraloral stripe and small lengthened subocular spot; sides of throat dull buff; sides of jugulum wood brown, inconspicuously streaked with dull brown; chin and throat white; breast and center of jugulum light cinnamon, the middle of breast whitish; abdomen dull white; sides of body brownish gray, with broad shaft streaks of bister; flanks dark brownish gray, rather broadly barred with white; under tail-coverts white, broadly barred with dark brownish gray; thighs anteriorly dull white, posteriorly mouse gray; lining of wing dark brownish gray, narrowly barred with white.

Measurements.-Adult female ${ }^{36}$ : Wing, $141.5 \mathrm{~mm}$; tail, 57; exposed culmen, 57 ; tarsus, 48 ; middle toe without claw, 43.

Type locality.-Ycacos Lagoon, British Honduras.

Geographic distribution.-Permanent resident in eastern British Honduras.

Remarks.-This new race is similar to Rallus longirostris corrius of the Bahama Islands but decidedly darker on the upper parts, particularly the centers of the feathers on the mantle. It is similar to Rallus longirostris caribaeus but has the upper parts, including the crown, much darker, the dark centers of the feathers being mostly black instead of olive-brown.

The only specimen of this new race that the writer has seen is the type, but the characters exhibited by this specimen are such that it apparently warrants separation as a new race. It appears to be confined to the coast region of eastern British Honduras.

\section{RALLUS LONGIROSTRIS TENUIROSTRIS Ridgway}

\section{Mexican Clapper Rail}

Rallus elegans var. tenuirostris RIDGway (Lawrence MS.), Amer. Nat., vol. 8, no. 2, p. 111, Feb. 1874 ("City of Mexico").

Subspecific characters.- Similar to Rallus longirostris cubanus, but tail and middle toe averaging somewhat longer; upper parts, particu-

${ }^{36}$ One specimen, the type. 
larly the edgings of the feathers, lighter, brighter, more rufescent (less grayish) (similar to the upper parts of Rallus elegans), cheeks more brownish, less clearly gray; bend of wing much more reddish, the cinnamon of the anterior lower parts darker, more pinkish, the jugulum without any indication of gray; sides and flanks lighter, the white bars averaging narrower and usually less distinct, often buff instead of white.

Measurements.-Adult male ${ }^{37}$ : Wing, 151-159.5 (average, 156.5) $\mathrm{mm}$; tail, 62-70.5 (66.5); exposed culmen, 62-65.5 (63.5); tarsus, 56-59 (57.8); middle toe without claw, 49-53 (51.1). Adult female ${ }^{38}$ : Wing, 139-144.5 (142.4); tail, 59-65 (62.9); exposed culmen, 56-60 (58); tarsus, 47.5-53 (51.3); middle toe without claw, 44.5-48 (46.6).

Type locality.-Mexico City, Mexico.

Geographic distribution.-Permanent resident in the Mexican States of Mexico and Tlaxcala, chiefly in the Valley of Mexico.

Remarks.-This rail is similar to Rallus longirostris caribaeus, but its bill averages somewhat longer; the centers of the feathers on the upper parts are darker, more blackish, but the edgings lighter and brighter, thus much more strongly contrasted; bend of wing decidedly more reddish; cheeks more brownish, less clearly grayish; anterior lower parts darker, brighter, more pinkish cinnamon and less uniform; sides and flanks darker, the white bars narrower and less distinct.

This is one of the most distinct of all the races of Rallus longirostris and as previously stated is the form that most closely approaches Rallus elegans in its rather rufescent upper parts and reddish bend of the wing, but the olive colors of the upper parts are not so rufescent or ochraceous as in the latter species. Furthermore, it is one of the few clapper rails that are strictly fresh-water birds, confined as it is to the Valley of Mexico.

In this species the color phases are not so well marked as in some of the other races, although there are two phases involving the color of the upper parts, a gray phase and a brown phase. The jugulum is lacking entirely in the suffusion of gray; but birds in the juvenal plumage are very dark above with little cinnamon below, the body below nearly all white, more or less spotted laterally with brownish slate.

The available specimens represent localities as below:

Mexico: Valley of Mexico. ${ }^{39}$

Tlax Cala: Lerma (July 2, 5, 6, 7, and 9, 1904).

${ }^{37}$ Four specimens, from the State of Tlaxcala, Mexico.

${ }^{38}$ Six specimens, from Tlaxcala, Mexico.

${ }^{30}$ Type. 


\section{RALLUS LONGIROSTRIS BELDINGI Ridgway}

Belding Clapper Rail

Rallus beldingi Ridgway, Proc. U. S. Nat. Mus., vol. 5, p. 345, [Sept. 11] 1882

("Espiritu Santo Islands, Lower California").

Subspecific characters.- Similar to Rallus longirostris ienuirostris, but bill shorter, tarsus and middle toe somewhat so; upper surface darker and duller, the bend of the wing less reddish; lower parts much darker anteriorly (but without gray on jugulum); sides and flanks much darker, the bars more whitish and much more distinct; chin less extensively white; and center of breast not so often white.

Description of soft parts.-Basal two-thirds of mandible and posterior portion of maxillar tomium deep orange; remainder of bill dark dull brown; end of mandible paler; feet dark brown.

Measurements.-Adult male ${ }^{40}$ : Wing, $147-160$ (average, 155.1) mm; tail, 55-73 (64.8); exposed culmen, 53-63 (56.2); tarsus, 48-57 (53.1); middle toe without claw, 43-50 (47.8). Adult female ${ }^{41}$ : Wing, 140-150 (144.8); tail, 54-68 (63.2); exposed culmen, 49-55.5 (52.7); tarsus, 45-53 (49.2); middle toe without claw, 40-47 (43.9).

Type locality.-Espiritu Santo Island, Lower California.

Geographic distribution.-Permanent resident in Lower California and its coastal islands, south to Cape San Lucas, and north to central Lower California; on the Pacific side to latitude $28^{\circ} \mathrm{N}$. (Scammons Lagoon, Viscaino Bay), and on the Gulf of California side to San Jose Island in latitude $25^{\circ} \mathrm{N}$.

Remarks.-Among the specimens of this race examined there seems to be not nearly as much individual variation evident as in most of the other races of this species. Only one phase of plumage seems to be present.

Specimens have been examined from the localities listed below:

Lower California: La Paz (January 4, 183-, February 18, 1906, April 28, 1913, May 3, 7, 11, and 15, 1913); one mile west of La Paz (January 4, 1929, May 20 and 22, 1929, February 18, 1929); three miles southwest of La Paz (January 2 and 31, 1929; May 24 and 25, 1929); San Jorge (April 24, 26, 27, 28, and 30, 1931); San Jose Island (June 20, 1930); Santa Margarita Island (June 7 and 10, 1931); Espiritu Santo Island (February 1, 1882). ${ }^{42}$

\section{RALLUS LONGIROSTRIS LEVIPES BangS}

\section{Light-Footed Clapper Rail}

Rallus levipes Bangs, Proc. New England Zool. Club, vol. 1, p. 45, June 5, 1899 ("Newport Landing, Los Angeles County, Calif.").

Subspecific characters.-Similar to Rallus longirostris beldingi, but wing, tarsus, and middle toe averaging somewhat longer; upper parts

40 Fourteen specimens, from Lower California.

41 Twelve specimens, from Lower California.

42 Type. 
lighter, the edgings more grayish (less rufescent) olive; lower surface anteriorly lighter, the chin more extensively white; sides and flanks averaging lighter, their white bars broader.

Description of soft parts.-Adult: "Iris dark brown; bill brownish orange at base, dusky along ridge and at tip; legs and feet dull orange brown, darkest at joints" (Grinnell, Bryant, and Storer). Nestling: "Bill dusky, with yellowish white band near end and yellow spot about nostril" (Grinnell, Bryant, and Storer).

Measurements.-Adult male ${ }^{43}$ : Wing, 154.5-167 (average, 161.9) mm; tail, 62.5-69 (66.7); exposed culmen, 56-61 (58.9); tarsus, 53-60.5 (56.9); middle toe without claw, 50-54 (51.2). Adult female ${ }^{44}$ : Wing, 138-155.5 (147.3); tail, 57-67 (62.6); exposed culmen, 51.5-58 (54.2); tarsus, 47-51 (49.5); middle toe without claw, 41-48 $(44.9)$

Type locality.-Newport Landing, Los Angeles County, Calif.

Geographic distribution.-Permanent resident on the coast of southwestern California, north to Santa Barbara, and south to northwestern Lower California (San Quintin Bay).

Remarks.-This form of the clapper rail resembles in a general way Rallus longirostris tenuirostris, but it differs in having a longer wing, shorter bill, lighter and brighter upper parts that are usually more rufescent olive, darker anterior lower parts, somewhat more deeply colored flanks and sides, and broader, more distinct, and more purely white bars on the flanks.

The jugulum in this race usually has no admixture or suffusion of gray, but occasionally has a slight wash of this color. The upper parts present two chief color phases, a brown, or rufescent olive, and a gray, both involving chiefly the edgings of the feathers. The lower parts, so far as known, have no gray-breasted phase.

Specimens have been examined from the following localities:

California: Sunset Beach, Orange County (December 18, 1918, January 23, 24, and 31, 1917, February 27, 1917, February 7, 1918, February 23, 1921); Santa Barbara (July 1, 1875); Wilmington, Los Angeles County (November 16, 1879); San Diego County (May 9, 1905 [nestling], October 20, 1906); False Bay (April 10, 1908); National City (December 4, 1886, October 19, 1917); Newport Landing (February 23, 1886); Pacific Beach, San Diego County (September 13, 1904, November 25 and 29, 1905); Bolsa Chica Club, Orange County (January 31, 1900); San Diego (May 9, 1905).

Lower California: San Quintin Bay (December 8, 1930); mouth of Tia Juana River (July 17, 1894).

${ }^{43}$ Ten specimens, from California and northern Lower California.

${ }^{4}$ Twelve specimens, from California and Lower California. 


\section{RALLUS LONGIROSTRIS OBSOLETUS Ridgway}

California Clapper Rail

Rallus elegans var. obsoletus Ridgway, Amer. Nat., vol. 8, no. 2, p. 111, Feb. 1874 ("San Francisco, Cal.").

Subspecific characters.- Similar to Rallus longirostris levipes, but tail longer; upper parts practically identical, but the cinnamon of the anterior lower parts decidedly paler and much less pinkish (more ochraceous), usually with a slight gray wash on the jugulum; sides and flanks averaging paler, the white bars on these parts slightly narrower.

Description.-Adult: "Iris dark brown or orange brown; bill reddish orange at base of lower mandible and along edge of upper, otherwise dusky olive brown; legs and feet dull orange brown, darkest at joints" (Grinnell, Bryant, and Storer). Nestling: Upper parts uniform glossy black with a greenish sheen; lower parts of body duller or more grayish black; basal half of bill blackish, terminal half whitish.

Measurements.-Adult male ${ }^{45}$ : Wing, 153.5-170 (average, 161.7) $\mathrm{mm}$; tail, 68-80 (73.1); exposed culmen, 55-66 (60.3); tarsus, 52-61 (56.7); middle toe without claw, $47-56$ (51.3). Adult female ${ }^{46}$ : Wing, 147-161 (151.6); tail, 60-76 (65.3); exposed culmen, 49-61 (55); tarsus, 45-63 (51.1); middle toe without claw, 44-51.5 (47.4).

Type locality.-San Francisco, Calif.

Geographic distribution.-Permanent resident in the coast region of central California; north to north-central California (Humboldt Bay), and south to south central California (Monterey Bay); accidental on South Farallon Island.

Remarks.-This is a very good subspecies, but it intergrades individually with Rallus longirostris saturatus. There are two color phases involving the upper surface, but no gray-breasted phase. In the brown phase the edgings of the upper parts are olivaceous, the centers of the feathers olive-brown. The gray phase differs from the brown phase in having much more grayish edgings on the feathers of the upper surface, particularly on the lower cervix, back, scapulars, and tertials, and also the dark centers of the feathers more blackish (less brownish). Specimens examined came from the localities here listed:

California: Alameda County (January 9 and 29, 1932, October 4 and 9, 1932); Palo Alto (March 29, 1901, October 20, 1907, January 19, 1908, October 1, 1909, October 1, 1916, August 4, 1899, September 16, 1899); Alviso (November - 1895, December 16, 1896); one-half mile north of Alviso (December 29, 1934); one mile north of Alviso (December 31, 1934); Point San Mateo (November 10, 1933); salt marshes, Marin County (October 30, 1877); San Francisco Bay

45 Twenty-nine specimens, from California.

${ }^{46}$ Twenty-four specimens, from California. 
(October 26, 1931); Bay Farm Island, Alameda County (April 3, 1915, October 3, 1925); Berkeley (November 27, 1891); Oakland (November 23, 1889); Redwood, San Mateo County (February 1, 1908, October 18, 20, 22, 23, 26, 28, 29, and 30, 1909); San Francisco (April -, 1877, March -, $1857^{47}$ ); Alameda (October 6, 1897).

\section{RALLUS LONGIROSTRIS YUMANENSIS Dickey}

Yuma Clapper Rail

Rallus yumanensis Dickey, The Auk, vol. 40, no. 1, p. 90, Jan. 10, 1923 ("Bard Imperial County, California”).

Subspecific characters.- Similar to Rallus longirostris obsoletus, but wing and bill somewhat shorter; upper surface more grayish, that is, the edgings of the lower cervix, back, and scapulars are usually (in normal phase) more grayish (less brownish or olivaceous); cheeks somewhat more clearly gray (less brownish); cinnamon of anterior lower parts brighter, more pinkish, usually somewhat lighter; abdomen dull white instead of buff.

Description.-Type, adult male, no. J-1039, collection of D. R. Dickey; Bard, Imperial County, Calif., May 15, 1921; Mrs. May Canfield. Forehead and crown between buffy brown and olive brown, the feathers with stiff, shiny, blackish-brown shafts; occiput and upper cervix grayish olive brown; middle cervix similar but lighter and with narrow light dull wood-brown edgings; lower cervix fuscous on the broad central stripes of the feathers, and between light grayish olive and drab on the broad margins; feathers of back and scapulars dark fuscous centrally, dull light grayish olive marginally, in places more brownish; rump and upper tail-coverts between deep grayish olive and hair brown, with shaft stripes of fuscous; tail fuscous, the feathers margined with the color of the rump, most broadly on the middle pair; primaries, primary coverts, and secondaries, fuscous; tertials and the innermost secondary like the scapulars, but the latter more brownish marginally; exposed surface of greater wing-coverts between buffy brown and Saccardo's umber, rather darker outwardly; inner median and inner lesser coverts between buffy brown and citrine drab; outer median and outer lesser coverts between snuff brown and Saccardo's umber; sides of head dull mouse gray, the lores darker and more brownish, the lower eyelid dull creamy white; supraloral stripe buffy white, flecked with rusty; malar stripe dull light pinkish cinnamon, fading to almost white anteriorly; sides of neck like the middle portion of cervix, but paler and more or less suffused with light pinkish cinnamon; chin and throat, white; jugulum and breast, avellaneous with a cinnamon tinge, paling to light avellaneous on the middle of breast; abdomen dull creamy white; sides, flanks, and crissum, deep grayish hair brown, the flanks lighter, all barred with white, the outermost

17 Type. 
feathers of crissum being nearly all white on their outer webs, the white bars on the sides about $1 \mathrm{~mm}$ wide, their brown interspaces about $8 \mathrm{~mm}$; thighs between drab and hair brown posteriorly, dull cream white anteriorly; lining of wing grayish hair brown with very narrow widely spaced bars of dull white.

Measurements.-Adult male ${ }^{48}$ : Wing, $156 \mathrm{~mm}$; tail, 71 ; exposed culmen, 58 ; tarsus, 51.5 ; middle toe without claw, 46 . Adult female ${ }^{49}$ : Wing, 142-148 (average, 145); tail, 62-63 (62.5) exposed culmen, 53.5; tarsus, 50 ; middle toe without claw, 44-45 (44.5).

Type locality.-Bard, Imperial County, Calif.

Geographic distribution.-Permanent resident in southeastern California, from the Colorado River above Yuma, north to the Laguna Dam, and west to Salton Sea.

Remarks.-In this race the jugulum is entirely without grayish tinge. In the three specimens examined there is no indication of any definite color phase, though a male taken on May 15, 1921, at Bard, Imperial County, Calif., is much lighter on the anterior lower parts and slightly paler on the flanks than the female taken on May 5, 1921, but it is otherwise the same. Perhaps a larger series would show the existence of definite color phases. The bird inhabits apparently only the fresh-water marshes and canals adjoining the lower Colorado River and Salton Sea. It has never been taken elsewhere. It undoubtedly is one of the rarest of the rails of this group, and on account of its limited distribution and the circumstances under which it must exist it is possibly already extinct.

The following specimens have been examined:

California: Bard, Imperial County (May 15, 1921, ${ }^{50}$ May 27, 1921).

\section{RALLUS LONGIROSTRIS RHIZOPHORAE Dickey}

Sonora Clapper Rail

Rallus obsoletus rhizophorae Dickey, Trans. San Diego Soc. Nat. Hist., vol. 6, no. 18, p. 235, Dec. 24, 1930 ("Tobari Bay, southern Sonora, Mexico").

Subspecific characters.- Similar to Rallus longirostris yumanensis, but upper parts darker, more grayish (less brownish); anterior lower parts somewhat paler and duller; sides and flanks more grayish and somewhat darker.

Measurements.-Adult male ${ }^{51}$ : Wing, 147-155.5 (average, 151.8) mm; tail, 60.5-65 (63.3); exposed culmen, 56-60.5 (59); tarsus, 54.558.5 (56.4); middle toe without claw, 45.5-51.5 (48.3). Adult female ${ }^{52}$ : Wing, 139.5-148 (142.6); tail, 58-65 (61.6); exposed culmen, 53-57.5 (55.2); tarsus, 49-56 (50.9); middle toe without claw, 42-47 (43.8).

\footnotetext{
${ }^{8}$ One specimen (the type), from southeastern California.

4? Two specimens, from southeastern California.

so Type.

${ }^{81}$ Five specimens, from Sonora, Mexico, including the type.

${ }^{52}$ Nine specimens, from Sonora, Mexico.
} 
Type locality.-Tobari Bay, southern Sonora, Mexico.

Geographic distribution.-Permanent resident in the coast region of central and southern Sonora, from Guaymas to the boundary of Sinaloa.

Remarks.-The jugulum in this subspecies is entirely without gray, being uniform cinnamon like the breast. Color phases are not so marked in this race, although there are two that are well defined, a brown and a gray, involving only the upper parts.

The following specimens have been examined:

Sonora: Tobari Bay (April 28, 1930, ${ }^{53}$ April 30, 1930, May 1, 1930); Guaymas (May 5, 1930); Viejo Yaqui Lagoon (May 12, 1930).

\section{RALLUS LONGIROSTRIS NAYARITENSIS McLellan}

\section{San Blas Clapper Rail}

Rallus nayaritensis McLellan, Proc. California Acad. Sci., ser. 4, vol. 16, no. 1, p. 9, Jan. 31, 1927 ("San Blas, Nayarit, Mexico").

Subspecific characters.- Similar to Rallus longirostris rhizophorae, but wing and tail shorter; upper parts darker, less grayish (more olivaceous); cinnamon on jugulum duller but yet without a gray wash.

Description.-Type, sex unknown, California Academy of Sciences no. 28184; San Blas, Nayarit, Mexico, October 19, 1925; Miss M. E. McLellan; original number, 483. Pileum fuscous, verging toward hair brown on the forehead, the feathers with stiff, shiny, blackishbrown shafts; cervix dark hair brown with narrow lighter edgings between drab and grayish olive, these edgings imparting a streaked appearance; back, upper tail-coverts, and tail, fuscous black, the feathers all edged with lighter, on the back with light grayish olive, on the upper tail-coverts with rather brownish deep grayish olive, and on the tail with a darker shade of the same; wings fuscous, the lesser wing-coverts with the outer portion of outer median and greater coverts more or less extensively rufescent brown, between snuff brown and Saccardo's umber, the inner coverts, tertials, and scapulars, broadly margined with dull grayish olive; sides of head mouse gray, rather darker on the lores, the auriculars washed with buff; supraloral streak creamy white; sides of neck mouse gray washed with buffy; chin and upper throat, white; malar stripe and jugulum between avellaneous and pinkish cinnamon; breast deep vinaceous cinnamon, posteriorly paling to light pinkish cinnamon; sides and flanks between hair brown and chaetura drab, narrowly barred with dull white, and posterior portion of flanks paler and washed with buff; abdomen creamy white, laterally washed with light pinkish cinnamon; lower tail-coverts between hair brown and chaetura drab, narrowly barred with white, anteriorly somewhat washed with buff, but the lateral 
feathers almost wholly white; thighs anteriorly buffy white, posteriorly dull hair brown; lining of wing between chaetura drab and fuscous, narrowly barred with dull white.

Measurements.-Nearly adult ${ }^{54}$ : Wing, $129 \mathrm{~mm}$ (in molt); tail, 56.5; exposed culmen, 59; tarsus, 50.5; middle toe without claw, 49.

Type locality.-San Blas, Nayarit, Mexico.

Geographic distribution.-Permanent resident on the coast of Nayarit (Tepic), north to central Sinaloa (Mazatlan).

Remarks.-Notwithstanding the fact that the description and characters of this race depend upon the single specimen, which is not quite adult, apparently in the fresh first autumn plumage, it nevertheless seems to be subspecifically separable from all the known forms of the species. It is very different from Rallus longirostris yumanensis, having the wing and tail shorter; the bill somewhat longer; upper parts very much darker and more grayish, the centers of the feathers more extensively blackish, their edgings more purely grayish; the white bars on flanks and crissum narrower; the remainder of the lower posterior parts more whitish medially, the cinnamon on the lower parts not so extensive, though this difference may be due in part to slight immaturity.

It is similar to Rallus longirostris obsoletus, but the wing, tail, and tarsus are shorter; the upper parts darker, more grayish (less brownish or olivaceous), the centers of the feathers more blackish; the anterior lower parts less extensively cinnamon and much brighter; the middle of the abdomen more nearly white; and the white bars on the flanks narrower.

\section{RALLUS LONGIROSTRIS SATURATUS Ridgway}

Louisiana Clapper Rail

[Rallus longirostris] d. var. saturatus RIDGway (Henshaw MS.), Bull. Nuttall Orn. Club, vol. 5, no. 3, p. 140, July 1880 (“Louisiana”).

Subspecific characters.-Similar to Rallus longirostris nayaritensis, but wing and tail longer; upper parts rather lighter, the edgings less purely grayish, the central portions of the feathers narrower; cinnamon of breast rather darker and duller; posterior lower parts less whitish on median portion; flanks and crissum with much broader white bars.

Description of soft parts.-Iris orange; inside of mouth yellow; culmen dull brown; gonys flesh color; sides of bill reddish yellow; legs pale plumbeous.

Measurements.-Adult male ${ }^{55}$ : Wing, 140.5-163 (average, 150.4) $\mathrm{mm}$; tail, 58-68 (63.6); exposed culmen, 54-69 (61.7); tarsus, 47-55 (50.9); middle toe without claw, $43-52.5$ (47.6). Adult female ${ }^{56}$ :

54 One specimen (the type), from San Blas, Nayarit, Mexico.

ss Twenty-three specimens, from Texas and Louisiana.

s6 Sixteen specimens, from Texas, Louisiana, and Mississippi. 
Wing, 131-154 (141.3); tail, 56-66 (60.9); exposed culmen, 55.5-64 (59.9); tarsus, 42-52.5 (47.7); middle toe without claw, 38-47 (43.9).

Type locality.-The Rigolets Lighthouse between Lake Borgne and Lake Ponchartrain, southeastern Louisiana.

Geographic distribution.-Permanent resident in the region of the coast of the Gulf of Mexico, east to southwestern Alabama (Perdido Bay), and west from southern Mississippi and southern Louisiana to central southern Texas (Brownsville). Casual southeastward to central western Florida (Seven Oaks on Tampa Bay).

Remarks.-This clapper rail differs from Rallus longirostris yumanensis in shorter tail and longer bill and in having the cinnamon of the anterior lower parts duller and less pinkish, the abdomen less purely white (somewhat more buffy), and the white bars on sides and flanks averaging wider. From Rallus longirostris obsoletus of California, which (in normal phase) it rather closely resembles, it may be distinguished by its shorter wing, tail, tarsus, and middle toe; rather broader dark centers of the feathers on the upper surface; lighter pileum, somewhat less trenchantly defined from the cervix; less deeply cinnamomeous anterior lower surface; rather darker flanks, the white bars averaging broader; lighter, less brownish, more grayish sides of head; less blackish lores; and broader, more distinct superciliary stripe. From Rallus longirostris cubanus it may be separated by its lighter upper and lower surface and broader white bars on the flanks; from Rallus longirostris caribaeus by the darker, more blackish feather centers of the upper parts, the darker cinnamon of the lower surface, and the darker flanks; and from Rallus longirostris limnetis on account of its longer wing and tail, somewhat shorter tarsus and middle toe; rather darker upper parts; darker cinnamon of the breast; rather broader white bars on flanks; and (in normal phase) jugulum less tinged with grayish.

In this race the jugulum is usually more or less gray, although there are specimens which lack practically all tinge of this colør. Throughout the range of this race as assigned there seems to be no geographic variation, since birds of southern Texas appear to be identical with those from Alabama. Individual variation is highly developed in this subspecies. The great range of difference involves not only color but size. The throat is sometimes almost pure white, varying from this to cinnamon buff; the breast and jugulum range from very pale to deep cinnamon, almost as dark as in Rallus elegans. The flanks are in some specimens light hair brown, in others decidedly blackish; the top of the head ranges from blackish brown to rather light rufescent brown; the centers of the feathers on the back and scapulars vary from blackish clove brown to rather ligbt rufescent brown; the edgings of the back and scapulars from nearly pure gray to olive gray and brownish olive gray. The white bars on the flanks 
range in width from 1.8 to $3.5 \mathrm{~mm}$, averaging about $2.5 \mathrm{~mm}$. There are at least five well-defined color phases-light brown, dark brown, light gray, dark gray, and gray-breasted. ${ }^{57}$

The following specimens have been examined by the writer:

Alabama: Dauphin Island (May 19, 1911, August 16 and 17, 1911); Perdido Bay (September 2 and 15, 1911); Grande Batture Island (May 23, 1911; September 5, 1911, July 21, 1911); Bayou Labatre (May 22, 1911, August 5 and 11, 1911); Petit Bois Island (August 30, 1911, June 3, 1914).

Florida: Seven Oaks (March 9, 1910).

Louisiana: Octave Pass, Mississippi River Delta (January 31, 1911, February 2, 3, and 4, 1911); Main Pass, Mississippi River Delta (January 31, 1910); Timbalier Island (May 25, 1895); Petite Anse Island (May 2, 1894); Raccoon Pass (May 19, 1895, May 20, 1897); Isle Derniere (May 21, 1894).

Mississippi: Biloxi (May 26, 1911); Bay St. Louis (September 23, 1898, April 19, 1902); Horn Island (July 3, 1913).

Texas: Padre Island (May 10 and 28, 1915; September 2, 5, and 6, 1914); Houston (June 14, 1922); Rockport (August 8, 1893; October 2, 1893); Corpus Christi; Peat Island, Laguna Madre (April 15, 1889); Galveston (February 28, 1877); Sabine (August 30, 1902); Tarpon (July 21, 22, 23, 24, 25, 26, 27, and 28, 1910; October 6, 9, 11, 12, 14, 16, and 17, 1910); Brownsville (July 19, 1891 [nestling]).

\section{RALLUS LONGIROSTRIS SCOTTII Sennett}

Florida Clapper Rail

Rallus longirostris scottii Sennett, The Auk, vol. 5, no. 3, p. 305, July 1888 ("Tarpon Springs, Florida").

Subspecific characters.-Similar to Rallus longirostris saturatus, but wing and tail somewhat shorter; upper parts much more deeply colored, the dark centers of the feathers more blackish, less olive brownish; breast and flanks darker, the white bars on the latter narrower; lower parts much more extensively grayish.

Measurements.-Adult male ${ }^{58}$ : Wing, $135-155$ (average, 146) $\mathrm{mm}$; tail, 56.5-72 (63.3); exposed culmen, 56-66 (61.6); tarsus, 42-55.5 (49.8); middle toe without claw, 39.5-49 (45.5). Adult female ${ }^{59}$ : Wing, 128.5-145 (137); tail, 54.5-63.5 (59.2); exposed culmen, 51.5-60 (55.9); tarsus, 42-51 (45.6); middle toe without claw, 37-45 (41.9).

\section{Type locality.-Tarpon Springs, Fla.}

\footnotetext{
${ }_{57}$ For detailed description of the differences between these color phases, see the introductory paragraphs, antea, pp. 318-319.

58 Twenty-three specimens, from Florida.

69 Eigbteen specimens, from Florida and Alabama.
} 
Geographic distribution.-Permanent resident in Florida; north on the southeastern coast to Jupiter, on the western coast north to northwestern Florida (Pensacola); and south to extreme southern Florida (Cape Sable). Casual northwest to southwestern Alabama (Perdido Bay).

Remarks.-The upper parts in certain specimens are very similar to those of Rallus longirostris nayaritensis, but on the average they are darker than in that form. The lower parts likewise are darker and duller, excepting the flanks. Compared with Rallus longirostris cubanus the present race has a somewhat shorter wing and shorter tarsus and middle toe; darker upper parts; slightly darker flanks, with slightly wider white bars; and in the gray-breasted phase the whole lower surface gray, either without cinnamomeous or nearly so.

In Rallus longirostris scottii there is much variation in the width of the white bars on the flanks; and the jugulum is nearly always more or less gray. There are four well-defined color phases; i. e. (1) (normal), brown above with gray below; (2) brown above with cinnamon below; (3) gray above with gray below; (4) and gray above with cinnamon below. The gray phases are well marked by the much more grayish (less ochraceous or brownish) edges of the feathers on the upper parts. There is a pronounced gray phase of the lower parts in which much of the cinnamon and the posterior whitish of abdomen are replaced by dark gray, making the whole under surface appear much darker, since what cinnamon there is left is much duller. As already mentioned this gray phase of the lower parts occurs in combination with the gray and brown phases of the upper surface.

A single specimen from the mouth of Perdido Bay in southwestern Alabama, taken on January 27, 1912, is, on the lower surface, a typical example of the present race, and is very dark above, although in this it is not extreme, and apparently verges a little toward Rallus longirostris saturatus. It is, however, doubtless a wanderer from eastward, for the breeding bird from Perdido Bay is practically typical Rallus longirostris saturatus. Three specimens from the eastern coast of Florida, a male taken 10 miles northwest of Palm Beach on May 28, 1920; one from Jupiter, March 6, 1920; and another from the same locality, March 20, 1921, are rather surprisingly absolutely indistinguishable from Rallus longirostris scottii, as comparison with an extensive series shows. Since these birds were taken so late in the season they evidently represent the breeding form of that part of the Florida coast, and indicate that the present race occupies the southern part of the peninsula on both coasts.

The following specimens have been examined by the writer:

Alabama: Mouth of Perdido Bay (January 27, 1912).

Florida: Pensacola (July 28, 1926); Westbay (April 27 and 28, 1926); Horseshoe Point (May 25, 1926); Tarpon Springs (April 17, 
1891, May 24, 1918, ${ }^{60}$ December - , 1886, January 8, 1887, December 27, 1887, January 16 and 23, 1892, March 20, 1892, December 5 and 20, 1889, November 23, 1889, May 3, 1890, February 17 and 28, 1888); Tampa Bay (September 8, 1899, April 30, 1880); Fort Myers (January 16, 1892); Hernando County (December 1, 1880); Suwannee River, Lafayette County; mouth of Suwannee River (March 27 and 30, 1890); Charlotte Harbor; Clearwater; Port Richey (May 26, 27, and 28, 1918); 4 miles southwest of Punta Gorda (June 26, 1918); Anclote Keys (June 5, 1918); mouth of Chassahowitzka River (May 30 and $31,1918)$; 10 miles northwest of Palm Beach (May 28, 1920); Jupiter (March 6, 1920, March 20, 1921); Goose Creek (March 13 and 16, 1920); East Goose Creek (November 22, 1917); St. Marks (May 18, 1926, nestling and adult; January 3 and 12, 1920); Seven Oaks (March 9, 12, and 15, 1910, June 1, 1899, October 21, 1903); Lukens (January 1, 1906); Anclote (April 15 and 27, 1899; March 1 and 8, 1897 ; February 27, 1897).

\section{RALLUS LONGIROSTRIS INSULARUM W. S. Brooks}

\section{Mangrove Clapper Rail}

Rallus longirostris insularum W. S. Brooks, Proc. New England Zool. Club, vol. 7, p. 53, June 24, 1920 ("Big Pine Key, Florida”).

Rallus longirostris helius Oberholser, Proc. Biol. Soc. Washington, vol. 33, p. 33, July 24, 1920 ("Sixth Key in the Newfound Harbor Group, southwest of Big Pine Key, Florida”).

Subspecific characters.- Similar to Rallus longirostris scottii, but tail somewhat shorter; upper parts lighter, the edgings of the feathers much paler, and much more clearly grayish, less olivaceous; lower surface much lighter, less grayish; white bars on the flanks broader.

Description.-Type of helius, adult male, U.S.N.M. no. 255254; Sixth Key in the Newfound Harbor Group, southwest of Big Pine Key, Fla., May 12, 1919; Paul Bartsch. Pileum olive brown, the centers of the feathers darker; hind-neck between Saccardo's umber and sepia, mixed with grayish feather edgings, which posteriorly impart a streaked appearance; back and scapulars with the feathers centrally sepia, marginally clear gray; rump and upper tail-coverts sepia, with broad, dull, olive-gray feather margins; tail between olive brown and fuscous, the shafts of the rectrices clove brown; wings dark olive brown, the outer and inner edges of the quills lighter, the superior coverts still lighter and inclining to cinnamon, the inner coverts washed with grayish; outer web of outermost feather of alula mottled and partly edged with pale cinnamon; sides of head rather dark neutral gray, the lores darker and more brownish, the supraloral stripe and line on the lower eyelid dull white; sides of neck light neutral gray washed with buffy, posteriorly darker, less purely gray, and indistinctly streaked with dull brown; chin and throat white;

oo Type. 
malar stripe pale ochraceous buff; center of jugulum and whole of breast, between pinkish buff and pinkish cinnamon, the middle of breast paler; abdomen dull buffy white; sides of body and flanks rather dark brownish gray, broadly barred with white; lower tailcoverts white, widely barred with dark brownish gray; lining of wing rather dark hair brown, outwardly washed with rusty, and narrowly barred with white; thighs anteriorly dull white, posteriorly mouse gray.

Measurements.-Adult male ${ }^{61}$ : Wing, $140-151.5$ (average, 146) mm; tail, 51-64 (58.6); exposed culmen, 59-62.5 (61.2); tarsus, 47-54 (50.8); middle toe without claw, 45-49 (46.1). Adult female ${ }^{62}$ : Wing, 129.5-136.5 (133.8); tail, 57-60 (58); exposed culmen, 53-59 (55); tarsus, 44-47 (45.1); middle toe without claw, 39-42 (40.5).

Type locality.-Big Pine Key, Fla.

Geographic distribution.-Permanent resident on the keys of southern Florida; northeast to Key Largo, southwest to Raccoon Key and Key West.

Remarks.-This very interesting and remarkably distinct race of the clapper rail seems to be confined to the Florida Keys. The jugulum is usually more or less gray, but sometimes the median portion is clear cinnamomeous. There are, as in most of the clapper rails, two color phases, involving, however, only the lower parts-one a dark phase, which is brownish gray anteriorly, the other a light phase, which is clear gray anteriorly or even without gray on the jugulum. The upper parts in both phases are alike.

The following specimens have been examined by the writer:

Florida: Key West (August 12, 1893, December 24, 1888); Key Largo (March 11, 1930); Big Pine Key (April -, 1930); Sixth Key in the Newfound Harbor Group (May 12, $1919{ }^{63}$ ); Raccoon Key (June -, 1889); Torch Key (March 25, 1930).

\section{RALLUS LONGIROSTRIS WAYNEI Brewster}

\section{Wayne Clapper Rail}

Rallus crepitans waynei Brewster, Proc. New England Zool. Club, vol. 1, p. 50, June 9, 1899 ("St. Mary's, Camden County, Georgia").

Subspecific characters.- Similar to Rallus longirostris insularum, but tail longer; gray edgings of the upper parts much darker and usually less purely gray; bend of wing and flanks darker.

Measurements.-Adult male ${ }^{64}$ : Wing, 135-152 (average, 145.1) $\mathrm{mm}$; tail, 57.5-72 (61.9); exposed culmen, 54-67.5 (62.2); tarsus, 46.5-53.5 (48.2); middle toe without claw, 40-48 (45.4). Adult

${ }^{61}$ Five specimens, from the Florida Keys, including the type of Rallus longirostris helius.

${ }^{62}$ Four specimens, from the Florida Keys.

63 Type of Rallus longirostris helius.

a Fifteen specimens, from South Carolina, Georgia, and Florida, including the type. 
female ${ }^{65}$ : Wing, 129.5-146.5 (138.4); tail, 56-63.5 (59.9); exposed culmen, 53-62.5 (58.7); tarsus, 43.5-50 (46.7); middle toe without claw, 41.5-47.5 (44.4).

Type locality.-St. Marys, Camden County, Ga.

Geographic distribution.-Atlantic coast region of southeastern United States. Breeds north to central eastern South Carolina (Santee River); and south to southeastern Georgia and northeastern Florida (Merritt Island). Winters north to central eastern South Carolina (Charleston) and south to southeastern Florida (Jupiter).

Remarks.-From Rallus longirostris saturatus this race differs in smaller wing, tarsus, and middle toe; in more grayish edgings of the feathers on the upper parts; and usually more grayish anterior lower surface; while from Rallus longirostris limnetis of Puerto Rico it may be separated by its shorter tarsus and middle toe; somewhat darker upper surface, with more blackish centers of the feathers and more purely gray (less brownish) edgings; as well as by its more grayish (less brownish) flanks. From Rallus longirostris leucophaeus of the Isle of Pines it is distinguished by shorter tarsus; rather lighter, less blackish, centers of the feathers of the upper parts, giving this area a lighter tone; somewhat lighter flanks and sides, with wider white bars; and darker remaining lower parts. It is similar to Rallus longirostris belizensis, which is of about the same size, but the edgings of the upper parts are deeper, more olive gray, and the breast is darker.

There seems to be no geographic difference in Rallus longirostris waynei, but the individual variation is great. The throat ranges from pure white to strongly tinged with buff; the breast from dark cinnamon without grayish tinge to pale cinnamon, with or without much gray admixture, or to entirely gray; the middle of the abdomen ranges from pure white or pale buff to white with a grayish cinnamon tinge; the flanks vary from gray to hair brown, sometimes dark, in other individuals light; the lower tail-coverts are sometimes much marked with dark brown, but in other individuals very little so. The bars on the flanks vary in width from 1.2 to $3.2 \mathrm{~mm}$, averaging about $2.5 \mathrm{~mm}$. There are in this race five well-marked color phases, four of them involving the upper parts only - a light gray, a dark gray, a light brown, and a dark brown phase, to which should be added a gray-breasted phase. This race is one of the two partially migratory forms of Rallus longirostris. and although it is found in the winter practically throughout its breeding range, locally in reduced numbers, it wanders to a considerable distance south of its summer home.

The following specimens have been examined by the writer in this connection:

${ }^{65}$ Sixteen specimens, from South Carolina, Georgia, and Florida. 
Florida: Amelia Island (December 15, 17, 25, and 29, 1906; April 10, 1906, September 6, 1906, August 29, 1906, October 2, 16, $17,18,20$, and 30, 1906, December 22, 28, and 29, 1905, January 11 and 25, 1906, November 27, 1905, February 8 and 9, 1906, May 9, 1906, June 26 and 27, 1906, October 17, 1901); northern Brevard County (April 4, 1905); Matanzas River (May 26, 1925); Anastasia Island (May 27, 1925); New Smyrna (May 23, 1925); Fort George, Duval County (January 21, 1917); Pilot Town; northern shore of Dimmits Creek, Indian River; Smyrna; Pallesier Creek (May 20 and 26, 1896).

Georgia: St. Marys, Camden County (March 18, 1878, ${ }^{66}$ March 7, 15, 19, and 22, 1878, April 4, 1878); St. Germania (January 1, 1879); St. Catharine Island (January 1, —); Sapelo Island (December 15,1883$)$.

South Carolina: Mount Pleasant (April 5, 1904, May 17, 1904, November 4, 1904, October 19, 1896); Frogmore (May 5, 1885); Christ Church Parish (May 6, 1911); Porchers Bluff, Christ Church Parish (April 29, 1911, May 6 and 12, 1911); Charleston (January 10 and 11, 1891); Santee Club, lower South Santee River (June 10, 1915); St. Helena Island (November 22, 1904); Stoner River (November 9, 1904); Warsaw Island (November 28, 1904).

\section{RALLUS LONGIROSTRIS CREPITANS Gmelin}

\section{Northern Clapper Rail}

[Rallus] crepitans Gmelin, Systema naturae, vol. 1, pt. 2, p. 713, 1789, before Apr. 20 ("Noveboraco") (based on "Clapper Rail" Pennant, Arctic zoology, vol. 2, p. 490, no. 407, 1785 ["New York"]; and "Clapper Rail" Latham, A general synopsis of birds, vol. 3, pt. 1, p. 229, no. 2, 1785 ["New York"]).

Subspecific characters.-Similar to Rallus longirostris waynei, but tarsus and middle toe longer; wing and tail somewhat longer; upper parts lighter and more uniform; lower surface lighter, less ashy (more cinnamomeous); white bars on the flanks averaging wider.

Description.-Adult: Iris raw umber or pale yellow; eyelids whitish; bill dull brown, the upper half of maxilla darker, the mandible and the edges of the maxilla rather yellowish brown; legs and feet grayish brown; claws darker. Nestling: Glossy black above with a metallic greenish sheen; duller with little or no gloss on the middle of the lower surface; basal half of bill blackish, the terminal half paler.

Measurements.-Adult male ${ }^{67}$ : Wing, $142.5-159.5$ (average, 151.1) $\mathrm{mm}$; tail, 55-69 (64.6); exposed culmen, 55-69.5 (63.3); tarsus, 48-56 (51.7); middle toe without claw, $45.5-53.5$ (48.8). Adult female ${ }^{68}$ : Wing, 135.5-160 (146.8); tail, 55-69.5 (61.9); exposed culmen, 53.5-67 (59.6); tarsus, 41-56 (48.1); middle toe without claw, 40-52 (45.9).

67 Twenty-one specimens, from New York, New Jersey, Massachusetts, Virginia, and North Carolina. ${ }^{\circ}$ Seventeen specimens, from New York, New Jersey, Virginia, and North Carolina. 
Type locality.-Hempstead, Long Island, N. Y ${ }^{69}$

Geographic distribution.-Atlantic coast of the United States. Breeds north to southern Connecticut (Saybrook) and south to central eastern North Carolina (Beaufort). Winters north to southeastern New York (Far Rockaway, Long Island), southern Connecticut, casually in southeastern Massachusetts (Kingston), and south to northeastern Florida (Amelia Island). Casual in northeastern Massachusetts, southeastern New Hampshire (Portsmouth), and southwestern Maine (York). Accidental in northwestern Vermont (Burlington); central western Virginia (Lexington); southeastern New York (Ossining); District of Columbia (Washington); and in the central eastern Bahama Islands (Watlings Island).

Remarks.-Notwithstanding its geographical separation, Rallus longirostris crepitans is in appearance very much like Rallus longirostris corrius from the Bahama Islands, but it is distinguishable from that race by its somewhat longer wing, longer bill and tarsus, as well as decidedly darker upper and lower surfaces. It may be distinguished from Rallus longirostris longirostris by larger size, lighter upper surface with less blackish centers of the feathers, and usually darker, more purely grayish sides of head; and from Rallus longirostris leucophaeus by its rather longer wing and tail, much shorter tarsus, paler, less grayish upper surface with less blackish (more brownish) centers of the feathers, paler, less blackish flanks and sides, with much wider white bars, and the paler, duller, and less pinkish (more buffy) cinnamomeous of lower parts.

Birds of this race from Smith, Cobb, and Isaacs Islands in Virginia are apparently typical in both size and color. A single bird from Charleston, S. C., taken on June 8, 1902, is evidently typical Rallus longirostris crepitans, but it doubtless represents a bird that had remained behind the northward bound migrants. Several breeding birds from central eastern North Carolina at Fort Macon, Hatteras, Pea Island, New Inlet, and Beaufort, are geographically and otherwise intermediate between Rallus longirostris crepitans and Rallus longirostris waynei, and although more grayish on the upper surface are not much darker than specimens of Rallus longirostris crepitans from New Jersey. While these birds are thus appreciably different from typical Rallus longirostris crepitans they are so close to this form that it seems best, at least for the present, to refer them to this race, rather than to give them a distinctive name.

Individual variation in this race is considerable but is not so marked as in some of the others. In the adult the throat varies from pure

${ }^{60}$ The New York specimens in Mrs. Blackburn's Museum, which Pennant and Latham cited as the basis of their descriptions, were sent by a correspondent who lived at Hempstead, Long Island, N. Y., so that in this as in other similar cases this place should be considered the type locality. 
white to buff; the breast from pale ochraceous, almost without a pinkish cinnamon tinge, to pinkish cinnamon; the jugulum is sometimes gray on the median area and sometimes without gray even on the sides; the flanks range from very light gray to rather deep grayish brown; the lower tail-coverts are either heavily or lightly barred or spotted; the bars on the flanks range in width from 1.2 to $4 \mathrm{~mm}$, averaging about $3 \mathrm{~mm}$; and the edgings of the back, scapulars, and the rest of the upper surface vary from almost pure gray to olive gray, the centers of the feathers from light olive brown to bister, and even occasionally to clove brown. There are about four fairly welldefined color phases, although they are not so well marked as in Rallus longirostris saturatus. There is a light grayish phase with gray jugulum; a light grayish phase, with cinnamon-buff jugulum; a dark olivaceous phase with a grayish jugulum; and a dark olivaceous phase with a cinnamon-buff jugulum. In the light phases the upper parts are relatively uniform, because of less difference between the centers of the feathers and the edgings. In the light grayish phase the upper parts have rather pure gray edgings, but in the dark olivaceous phase the edgings are olive gray.

Individual differences in the juvenal plumage are almost as conspicuous as in the adults, the upper parts varying from purely grayish to dull brownish, the lower parts from almost pure white on the throat and abdomen to a strongly buffy or cinnamomeous or even pinkish tone.

The following specimens have been examined by the writer:

Connecticut: New Haven (September 10, 1884); Stamford (June 17, 1893); West Haven (May 30, 1904).

Florida: Amelia Island (January 11, 1906, September 6, 7, and 13, 1906).

Georgia: St. Marys; Sapelo Island (December 16, 1887); Savannah.

Maryland: Point Lookout (September 8, 1880).

Massachusetts: Ipswieh (October 20, 1910).

New Jersey: Tuckerton (June 18, 1918, nestling); Cape May (May -, 1842, May 6, 1880, May 15, 1877, May 20, 1881, May 22, 1882, May 14, 1881); Avalon (September 22, 1902); Atlantic City (July 23, 1893, May 14, 1881, October 2, 1894); South Amboy (May 12, 1879); Brigantine (June 3, 1882).

New York: Amityville (June 28, 1887, September 3, 1898); Somers Point (August 29, 1887); Hempstead Bay (September 13, 1907); Freeport (May 30, 1913, July 10, 1913, August 9, 16, and 18, 1913, July 11, 1901); near New York City (August 27, 1908, August 29, 1909). 
North Carolina: Fort Macon (April 22, 1869, April 11, 1891); Hatteras (March 2, 3, 6, and 7, 1900, April 3, 7, and 24, 1900, May 5, 1900, January 13, 1900, November 7 and 12, 1899, August 20 and 25, 1900, November 6 and 7, 1900); Beaufort (September 15, 1932, October 18, 1932, May 30 and 31, 1932); New Inlet (August 19, 30, and 31, 1904); Pea Island (May 1, 2, 5, 8, and 10, 1902, February 9, 11, 13, and 16, 1901, December 17, 1908, May 20, 1901, August 11, 19, 24, 30 and 31, 1904, January 16, 1904, December 17, 1904).

South Carolina: Stoner River (November 4 and 9, 1904); St. Helena Island (November 22, 1904); Port Royal (February 10, 1891); Lady Island; Mount Pleasant (June 8, 1902, January 10 and 11, 1891).

Virginia: Smith Island (September 6, 7, 10, and 11, 1899, September 17, 1898, June 10, 1897, May 24, 1898, May 3, 10, 12, 20, and 23,1899, April 30, 1899, August 18, 1899); The Isaacs (May 24, 1899); Cobb Island (June -, 1881, June 25 and 28, 1907, June 30, 1890, July 9, 1881, July 13, 1899, July 16, 1884, July 23, 1880); Lexington (autumn, 1928); Wachapreague (May 13, 1913); Bone Island (July $14,1880)$. 


\section{$2 \mathrm{BHL}$ Biodiversity Heritage Library}

Oberholser, Harry C. 1937. "A revision of the clapper rails (Rallus longirostris Boddaert)." Proceedings of the United States National Museum 84(3018), 313-354. https://doi.org/10.5479/si.00963801.84-3018.313.

View This Item Online: https://www.biodiversitylibrary.org/item/32837

DOI: https://doi.org/10.5479/si.00963801.84-3018.313

Permalink: https://www.biodiversitylibrary.org/partpdf/4226

\section{Holding Institution}

Smithsonian Libraries

\section{Sponsored by}

Smithsonian

\section{Copyright \& Reuse}

Copyright Status: NOT_IN_COPYRIGHT

Rights: https://www.biodiversitylibrary.org/permissions/

This document was created from content at the Biodiversity Heritage Library, the world's largest open access digital library for biodiversity literature and archives. Visit BHL at https://www.biodiversitylibrary.org. 